\title{
FISCAL DECENTRALIZATION AND LOCAL PUBLIC INVESTMENT POLICY IN THE REPUBLIC OF SERBIA
}

\author{
Sasa Randjelovic ${ }^{*}$ and Svetlana Vukanovic ${ }^{2}$ \\ 'University of Belgrade, Faculty of Economics, Belgrade, The Republic of Serbia \\ ${ }^{2}$ The World Bank, Belgrade, The Republic of Serbia
}

This paper analyses the level of fiscal decentralization and structural characteristics of local public finances in Republic of Serbia with focus on local public investments. Share of central government expenditures in consolidated government spending of $83 \%$, indicates relatively high degree of fiscal centralization. In spite of significant rise in local public revenues in the last decade public investments remained low - amounting to 1\% of GDP, which is significantly below EU and Central and Eastern Europe average (1.4 and 1.5\% GDP, respectively). Our results indicate large variation in relative size of public investments across LSGs. Most local public investments are focused on roads maintenance administrative infrastructure, while investments in environment and education are low. To tackle local disparities in terms of quality of local infrastructure and to foster economic convergence, development of planning and implementation capacities and introduction of systemic incentives for local public investments should be considered.

Keywords: fiscal decentralization, local self-government, public finance, local-level public investments

JEL Classification: H70, H71, H72, H74

\section{INTRODUCTION}

The territorial and political organization of the state are largely determined by the way it has been formed, its cultural heritage, as well as the socio-political and economic characteristics of society. In this regard, one of the relevant issues in the domain of fiscal federalism refers to the optimal level of distribution of functions and resources by the levels of government and the

* Correspondence to: S. Randjelovic, University of Belgrade, Faculty of Economics, Kamenicka 6, 11000 Belgrade, The Republic of Serbia; e-mail: sasa.randjelovic@ekof.bg.ac.rs impact of fiscal decentralization intensity on the overall economic performance of the state - primarily on long-term economic growth. Except for European transition economies, the levels of decentralization are relatively stable over time, revenue collection being relatively more centralized than expenditures (Dziobek, Mangas \& Kufa, 2011). Theoretical arguments in support of fiscal decentralization are based on the so-called Tiebaut's model, which suggests that the existence of more political units (e.g. local governments) allows people to relocate in order to choose the one that best reflects their preferences, in 
terms of the quality of local public goods and services, and the amount and structure of taxes (Tiebaut, 1956). Therefore, it is considered that the existence of a larger number of local governments enables the adjustment of their policies to the preferences of their inhabitants, which has a positive effect on the overall social welfare (Stigler, 1957). This would indicate that fiscal competition between local governments leads to efficient resource allocation, which positively affects overall economic efficiency (Oates, 1972). These theoretical views are supported by some empirical research, which shows that the existence of a larger number of local governments per 100 thousand inhabitants, has a positive impact on local economic development (Akai \& Sakata, 2002; Stansel, 2005). On the other hand, there is also a relatively large body of empirical studies that suggests a negative link between fiscal decentralization and economic growth (Martinez-Vazkues \& McNab, 2003; Bodman, 2011; Baskaran \& Feld, 2013).

The results of theoretical and empirical analyses also indicate that the link between fiscal decentralization and economic growth is not linear, but rather depends on the degree of decentralization, transparency of public finance, design of incentives created by the financing system, and the efficiency of use of public resources at the sub-central levels of government (Bird, 2000). Recent empirical research indicates that one of the main reasons for the relatively slow growth of the the economy of Republic of Serbia in the past two decades (compared to the growth achieved by, for example, Asian countries when they were at the same level of development), is the low level of investment - public investment, as well as domestic private investment (Arsić, Ranđelović and Nojković, 2019). Insufficient level of consolidated government public investment is a consequence of low investments of the central as well as the local government. At the same time, in the past few years, public investments at the central level of government have increased significantly, while local public investments have remained relatively low, despite the additional decentralization of public revenues (Ranđelović, 2020). Considering relatively significant size of fiscal multipliers with public investment in emerging European economies, found in empirical studies (Petrović, Arsić \& Nojković, 2021), low public investment triggers significant losses in terms of the foregone future economic growth. Therefore, in order to encourage long-term economic growth, in addition to numerous other preconditions, it is necessary to improve institutional mechanisms that would provide a relatively high level of public investment at all levels of the state, the implementation of which would be transparent and efficient.

This paper is dealing with the evaluation of the state of fiscal decentralization in Republic of Serbia, the performances of local self-government (LSG) financing system, and the characteristics of local public expenditure policy, with the focus on LSG public investment policy.

In that respect, we test two main hypotheses:

H1: Local public investment in the Republic of Serbia are low.

$\mathrm{H} 2$ : Revenue decentralization, without introduction of systematic incentives, does not trigger automatic rise in local public investment.

The aim of these analyses is to provide wellgrounded evaluation characteristics of institutional arrangement related to LSG financing in Republic of Serbia and to identify areas for improvement of LSG financing mechanisms, aimed at promoting local public investment policy and fostering local economic development. The analysis in this paper is conducted using the methods of descriptive statistics, applied to the aggregated (macro-level) data available in the Public Finance Bulletin, for the period 20102019. Evaluation of variation in structural features of local public finance policy is done using the LSGlevel data for 27 sample cities and municipalities, for which the data on budget realization were collected by the authors. Sample LSGs account for 52\% of total population in Republic of Serbia, $59 \%$ of total expenditures of LSGs and $62 \%$ of total revenues of LSGs.

The remaining of the paper is structured as follows. Section 2 provides insight into the key facts on the territorial organization and fiscal decentralization in 
Republic of Serbia. Section 3 discusses LSG financing instruments and performances, while section 4 is dealing with the analysis of the state, structure and dynamics of LSG public expenditure policy, with the special focus on local public investment policy. Section 5 evaluates the institutional framework and performances in terms of fiscal balance and debt of LSGs, while the section 6 concludes.

\section{TERRITORIAL ORGANIZATION AND FISCAL DECENTRALIZATION IN REPUBLIC OF SERBIA}

Republic of Serbia is organized as unitary country, with dominant central government level and subcentral government levels consisting of local selfgovernments and autonomous provinces. Local selfgovernments can take the form of municipalities (normally above 10 thousand citizens) and cities (with more than 100 thousand citizens). These limits for formation of municipalities and cities can be alleviated for economic, geographical and historical reasons, which means that municipalities and cities may be formed even if the total population is less than 10 and 100 thousand respectively. According to the Law of Territorial Organization of the Republic of Serbia (2007), the territory of Republic of Serbia consists of 145 LSGs: 117 municipalities, 27 cities and the capital city (Belgrade). In addition to that, in Republic of Serbia there are 24 districts, which are defined as administrative units, without real functions and effective budgets.

Mean population per LSG in Republic of Serbia is close to 48 thousand, which is by $37 \%$ higher than the European Union (EU) or the Western Balkans (WB) average. On the other hand, mean land area of Serbian LSG is $534 \mathrm{~km}^{2}$, which is close to the EU average and somewhat higher than the WB average (Figure 1). These data indicate that LSGs in Republic of Serbia are rather large, especially in terms of population, in comparison with the prevailing European practice.

Territorial organization may shape to some extent the fiscal decentralization of a country. Fiscal

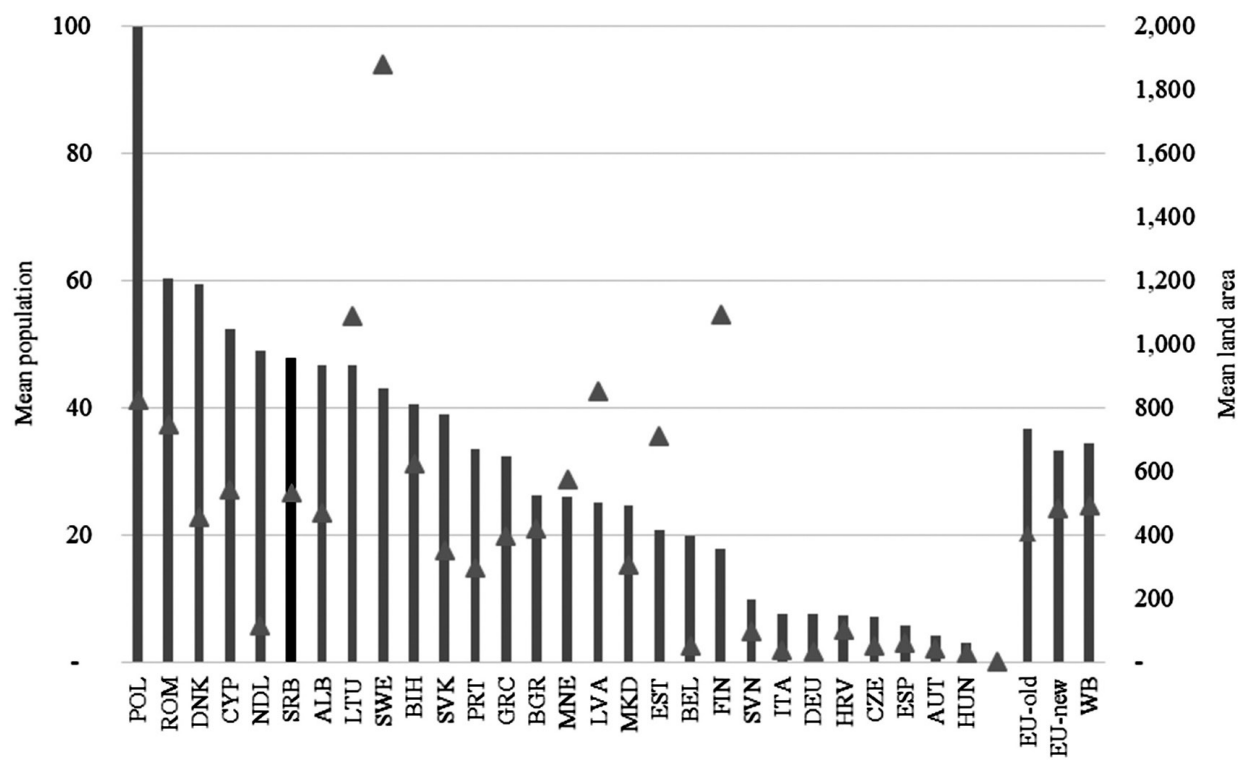

- Mean population per LSG ('000)

$\Delta$ Mean land area per LSG $(\mathrm{km} 2)$

Figure 1 Mean population per LSG ('000) and mean land area per LSG ( $\left.\mathrm{km}^{2}\right)$ in Europe 
decentralization can be measured in different ways, the coefficient of centralization - the share of central government expenditures in consolidated government expenditures, being one of the common indicators (Rosen \& Gayer, 2014). Due to unitary character of the government, 83 percent of consolidated government expenditures in Republic of Serbia are attributed to central government (budget of Republic of Serbia, social security institutions, etc.), which is above the EU-27 and the Western Balkans average (Figure 2). The data presented in Figure 2 suggest stronger fiscal decentralization in developed European countries than in emerging Europe. This is in line with the findings in other empirical studies based on the more sophisticated methodology that takes into account not only the budget allocation across the levels of government, but also the effective fiscal autonomy, in terms of functions and powers (Aristovnik, 2012; Molnar, 2014).

\section{LOCAL SELF-GOVERNMENTS' FINANCING}

\section{Institutional framework}

Financing of LSGs in Republic of Serbia is regulated by the Law on Local-Government Financing. Pursuant to the article 2 of that law, there are three groups of LSG financing instruments: own-source revenues, assigned revenues and central-government grants. Own-source revenues are revenue-raising instruments that are designed, imposed and collected by a LSG, which means that LSG is relatively free to decide on its characteristics, parameters and amounts. These are: recurring property tax, local administrative and communal taxes, tourist fees, public goods usage fees, concession fees, some fines and penalties, income from rental of assets owned by LSG, self-contribution, grants, etc. Assigned revenues are instruments designed, imposed and collected by the central government and then assigned to LSGs based on the statutory criteria. There are several types

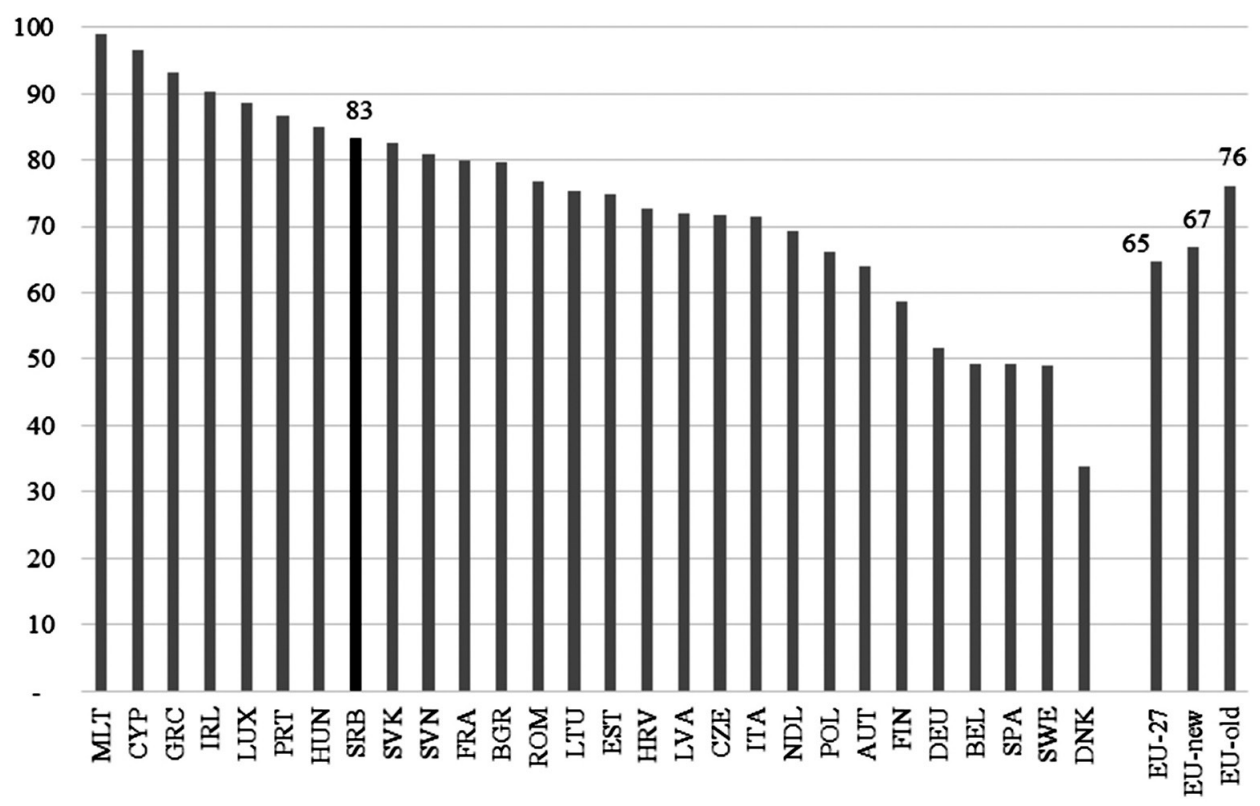

Figure 2 Coefficient of centralization in Europe in 2019 (\%)

Source: Authors 
of assigned revenues: $74 \%$ of wage tax revenues, full amount of other personal income taxes, inheritance and gifts tax and property transfer tax.

Central-government grants are transfers provided from the central government budget to LSGs budgets, in the form of Non-targeted or Targeted grants. Nontargeted grants are divided into: Equalization grant, General grant, Compensating grant and Solidarity grant. The total amount of Non-targeted grants is set out by the Law on Local Self-Government Financing (2006), at $1.7 \%$ of GDP. This amount is primarily used to finance Equalization grant that is aimed to assist LSGs, which underperform in terms of assigned revenues, due to underdevelopment. Equalization grant is paid to LSGs that have per capita assigned revenues below $90 \%$ of the average per capita assigned revenues in all LSGs in Republic of Serbia. Compensating grant is designed to compensate LSGs which lost revenues due to change in tax legislation, imposed by the central government. This grant should compensate LSGs for a fraction of foregone (assigned) tax revenues, so that the relative decline in the central and local governments' tax revenues is the same. General grant is provided to all LSGs. The maximum amount of the General grant is derived by subtracting Equalization and Compensating grants from the total amount of Non-targeted grants. According to the art 42 of the Law on Local Self-Government Financing (2006), there are several criteria based on which the amount of the General grant per LSG is calculated: LSG population $(65 \%$ of the General grant), total land area of LSG (19.3\%), number of classes in the primary schools $(4.56 \%)$, number of primary schools $(1.14 \%)$, number of classes in the secondary schools (2\%), number of secondary schools $(0.5 \%)$, number of children entitled to childcare service $(6 \%)$, number of childcare institutions (1.5\%). The amount of Equalization, Compensating and General grants for each LSG are corrected by the development coefficient that ranges from 0.5 to 1 , in order to protect underdeveloped LSGs and to foster their economic growth. The amount of Equalization, General and Compensating grants, intended for the City of Belgrade is used to create fund for the Solidarity grant, which is disbursed to other LSGs based on their level of development.
Targeted grants can take the form of Functional and Strictly-targeted grant. Functional grant is aimed to provide funds to LSG needed to finance additional expenditures incurred by a LSG, due to shift of functions of powers from the central government to LSG. In a similar way, the central government may provide Strictly-targeted grant to LSGs, requiring from them to use that grant solely for delivery of a specific function as set out by the law. To ensure transparency of disbursement, data on Non-targeted grants provided to each LSG need to be disclosed in the Fiscal Strategy. However, in practice these data are not publically disclosed on a regular basis.

Description of the LSG financing scheme suggest that size of the LSG budget depends on its size, level of development, functions, features of public services, etc. while the efficiency of expenditure size of the budget (structure of expenditures) and local tax revenue-raising efforts have no direct impact on revenue allocation by LSGs. This means that the LSG financing scheme creates no systemic (positive) incentives in terms of (own-source) revenue raising as well as in terms of productive allocation of resources (Arsić, Ranđelović, Bućić and Vasiljević, 2012).

\section{Revenue performances}

Total revenues of LSGs in Republic of Serbia (including central government grants) in 2019, amounted to EUR 2.7 billion, which is equivalent to $5.9 \%$ of GDP. In relative terms, LSG revenues in Republic of Serbia are considerably below the EU average ( $9.9 \%$ of GDP). However, when benchmarked against the countries from the new EU member states from the Central and Eastern Europe (CEE), which are more comparable to Republic of Serbia, the difference is notably smaller (Figure 3). LSG revenues in Republic of Serbia account for $14 \%$ of consolidated government revenues, which is significantly below the EU-27 average (22\%) and the new EU member states average (20.7\%). This is the consequence of variation in territorial organization as well as vertical allocation of government functions. As a result of changes in LSG financing regulations and revenue collection efforts, the total LSG revenues in Republic of Serbia in 2019 rose by 15\% in real 
terms, comparing to 2010, mostly due to increase in wage tax and property tax revenues, while the central government grants remained almost unchanged.

Public health crisis caused by the COVID-19 pandemic has had considerable negative impact on economic trends in the most of the world. Many countries, including Republic of Serbia reacted through massive fiscal stimuli, which included the offer to corporate sector to defer payment of taxes, which has considerably dampened pandemic recession (Ranđelović, 2021). However, the data of the Ministry of Finance show that in 2020 tax revenues of LSGs in Republic of Serbia posted mild nominal growth (while in real terms they stagnated), while the total revenues of LSG posted mild nominal decline of $2.8 \%$ (Ministry of Finance, 2020). This is, inter alia because large part of LSG tax revenues comes from the taxes with the stable tax base (e.g. property taxes). As government subsidies prevented massive rise in unemployment, wage tax revenues have been stable as well. At the same time, LSGs adjusted their public expenditures, which in total decline by $3.4 \%$ in comparison with 2019 .
Revenues from personal income tax account for $40 \%$ total LSG revenues, more than $4 / 5$ of these revenues being related to wage taxes. The second largest financing instruments are recurrent property taxes, followed by the central government grants. These three financing instruments account for more than $70 \%$ of LSGs revenues, while the remaining part of revenues comes from inheritance and gifts tax, property transfer tax, signboard tax, other local communal and administrative taxes and fees, as well as other non-tax revenues.

Revenue structure (Figure 4) also indicates dominance of assigned revenues and grants, while the share of revenues that are parametrized and raised by the LSGs is relatively low, which to certain extent limits their autonomy. This is the consequence of the design of the public finance system, lack of incentives, and the relatively low revenue-raising efforts of LSGs.

According to municipal level data, average per capita revenues in the sample of 27 LSGs, amount to RSD 50,600. Distribution of per capita revenues across LSGs indicate relatively high inequality in terms of

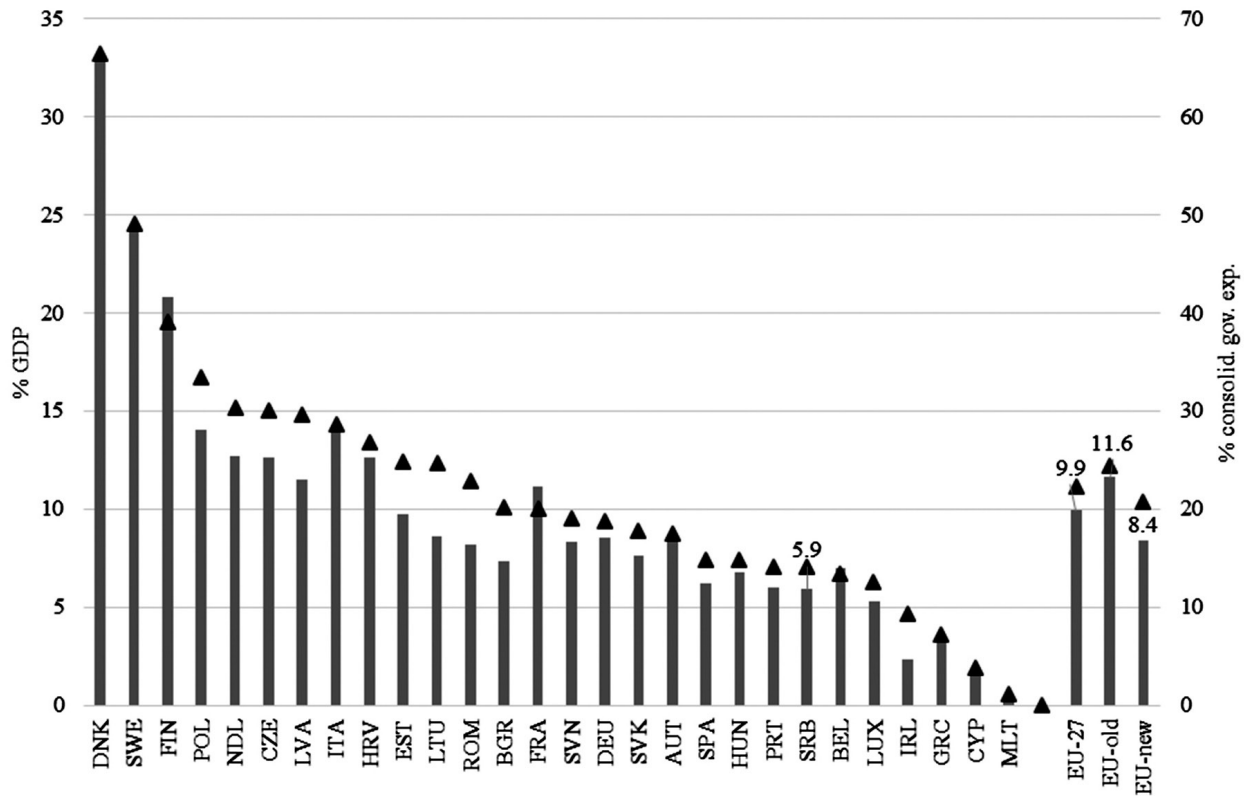

Figure 3 LSG public revenues in Republic of Serbia and Europe 
revenue allocation. Average coefficient of variation in the sample of 27 LSGs amount to 37 (Figure 5), which is the consequence of the design of LSG financing system and regional inequalities in terms of economic development. Inequality in revenue distribution is then translated into inequality in expenditures distribution, including inequality in local public investment (Figure 10), with adverse impact on local and regional disparities in terms of economic development.

\section{LOCAL SELF-GOVERNMENTS' EXPENDITURE POLICY}

\section{Institutional framework}

Functions and operations of LSGs in Republic of Serbia are regulated by the Law on Local Self-Government (2007). In overall terms, functions of LSGs in Republic of Serbia are similar to the roles assigned to LSGs in many other European countries:
- to make local economic development plans and facilitate doing business condition and inflow of investment;

- to provide local/communal services (e.g. waste and water management, heating, etc.), public transportation and to use construction land and business premises;

- to develop, maintain and manage local roads and other public infrastructure;

- to assist provision of services in education (preschool, primary and secondary), primarily in terms of development and maintenance of education infrastructure (school buildings and equipment);

- to facilitate provision of services in research and innovation, culture, healthcare (maintenance and development of primary healthcare infrastructure), social protection and sports;

- to foster development of tourism, handcraft industry, trade and hospitality;

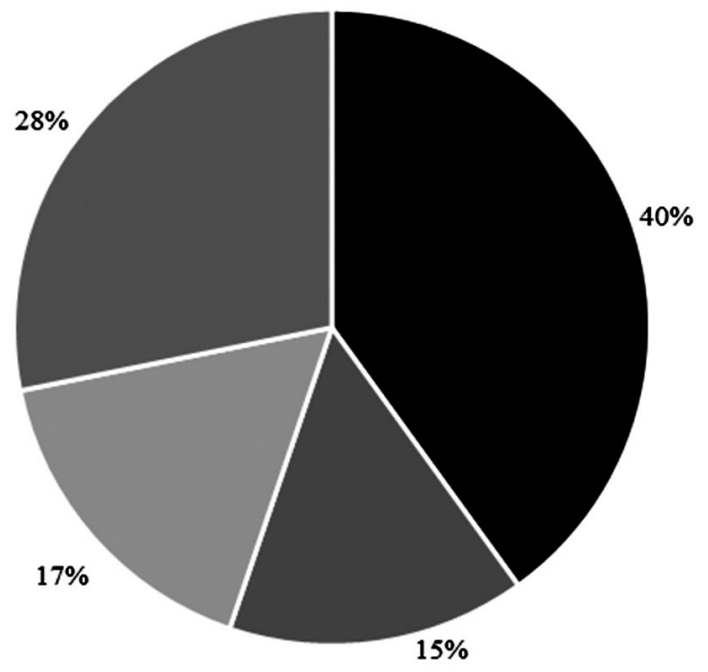

- Personal income tax - Grants = Property taxes - Other tax and non-tax revenues

Figure 4 Composition of LSG revenues in Republic of Serbia in 2019 (\%) 


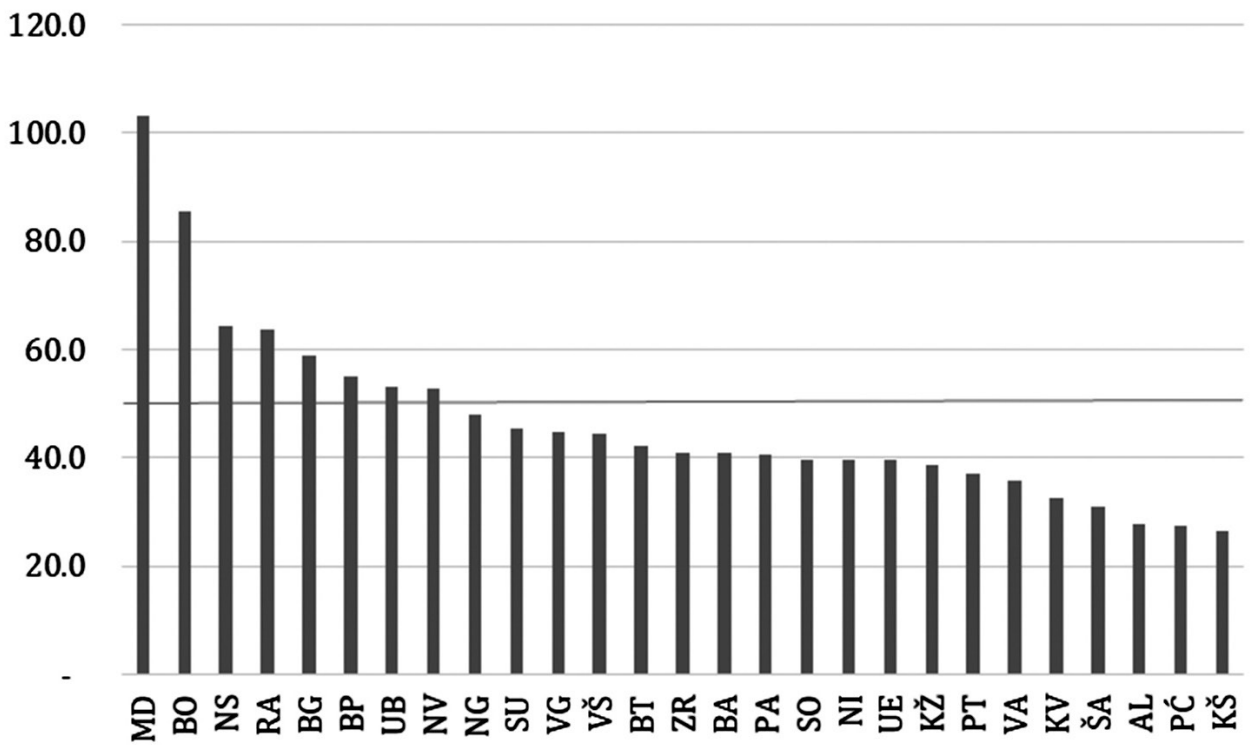

Figure 5 LSG revenues per capita in 2019 (RSD thousand) ${ }^{\text {ii }}$

Source: Authors

- to provide other services which are important for local development (construction permitting, firework protection, etc.).

Regulation and oversight of LSGs operations are done by the Government of the Republic of Republic of Serbia - Ministry of Public Administration and Local Self-Governments.

\section{Expenditure composition and trends}

The total expenditures of LSGs in Republic of Serbia in 2019 , amounted to $6 \%$ of GDP, i.e. $14.1 \%$ of the consolidated government expenditures. Expenditures on goods and services represent the single largest expenditure item, with the share of $36 \%$ in the total spending, followed by other outlays - mostly related to social protection (22\% of total spending) and wages (19\% of total spending), while capital expenditures accounted for around one sixth of the total LSG spending (Figure 6).

Due to rise in revenues and inflation, LSG expenditures in Republic of Serbia rose in nominal terms by $71.7 \%$ from 2010 to 2019, while real growth (inflation-adjusted) amounted to $19.2 \%$ (Figure 7). This has been to large extent driven by the rise in spending on goods and services (which rose by $90 \%$ in real terms over that period). Increase in unproductive expenditures has been encouraged by buoyant inflow of revenues (due to reform of wage tax allocation in 2011), as well as by rather low level of accountability in terms of local public finance management and the fact that over that period there was a hiring freeze in the public sector, which is why many LSGs have started to outsource services that used to be provided internally.

\section{Local public investment policy}

Since 2011, capital expenditures (i.e. public investment in local infrastructure) have been on decline until 2015, in spite of inflow of additional tax revenues due to the reforms legislated in 2011 and 2014. LSG public investment started picking-up yet in 2015 and since then they are rising steadily. However, in 2019 LSG public investment amounted to approx. EUR 450 million, thus still being lower, by $13 \%$ in real terms, than in 2010. In relative terms, LSG public 


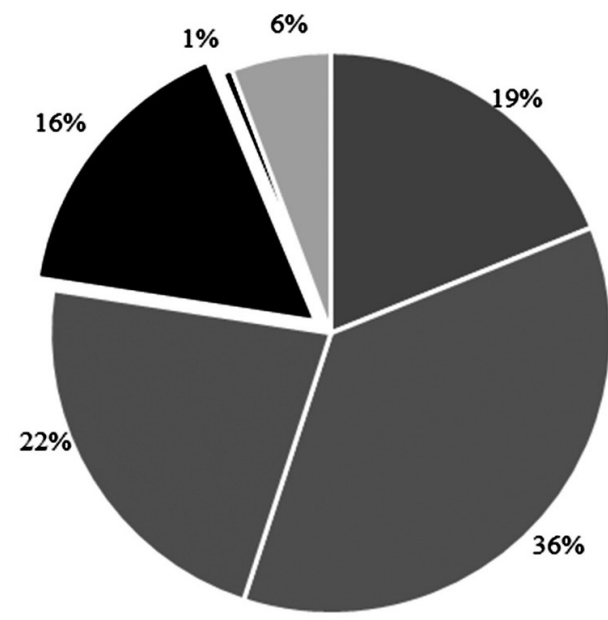

-Wages - Goods and services = Other outlays - Capital expenditures - Interest payments " Subsidies

Figure 6 Composition of LSG expenditures in Republic of Serbia in 2019 (\%)

Source: Authors

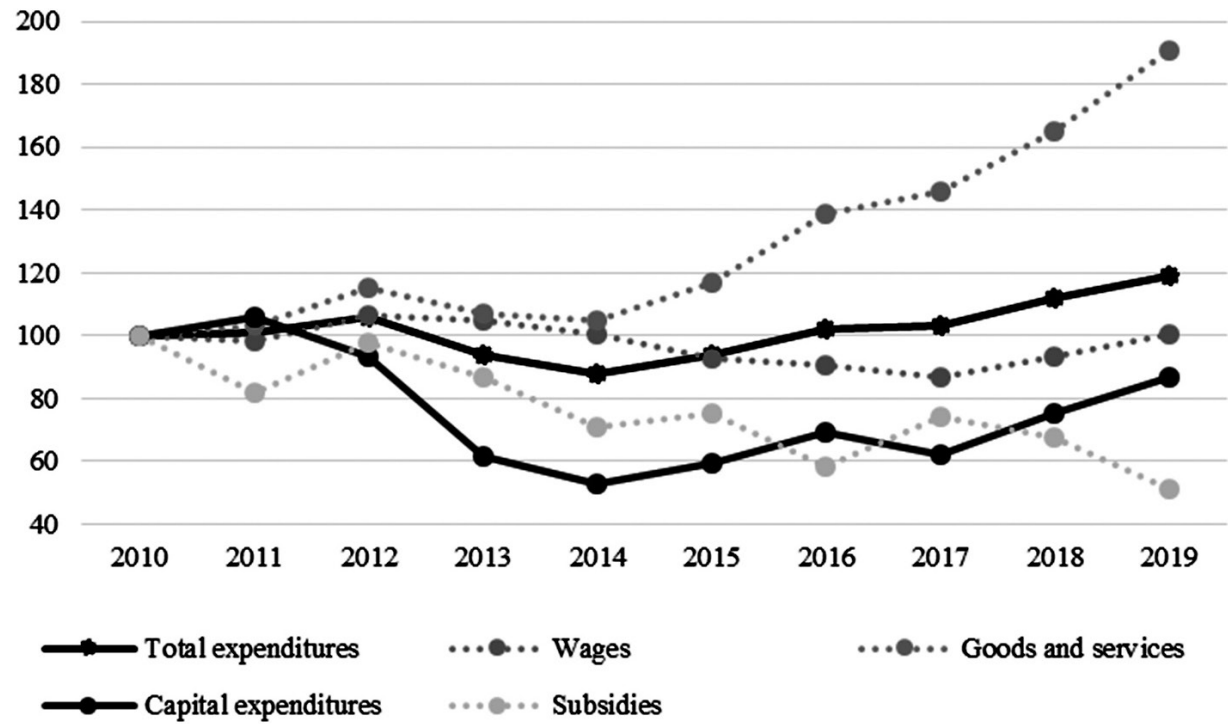

Figure 7 Index of real trends in LSG expenditures (2010=100)

Source: Authors 
investment in 2019 (Figure 8) amounted to 1\% of GDP, thus accounting for only one fifth of the consolidated government public investment.

Although starting from 2015 the LSG public investment have been on the rise (both in nominal and in real terms), they rose at the slower pace than the central government investment, which is why the share of LSG public investment in the consolidated government public investment was on a continuous decline since 2011. Thus in 2011, LSG public investment accounted for $40 \%$ of the total consolidated government public investment, while by 2019 that share has been halved (Figure 9).

In comparison with the other European countries, the total LSG public investment in Republic of Serbia are significantly below the EU-27 average $(1.4 \%$ of GDP) and the CEE average (1.5\% of GDP). New EU members from CEE tend to invest more from LSG budgets, than the developed European countries, in order to converge in terms of development of local infrastructure. Relatively low LSG public investment in Republic of Serbia in comparison with the other CEE countries may be, to some extent, explained by the lower local-level public spending. However, the data suggest that Republic of Serbia underperforms also in terms of the share of public investment in the total LSG expenditures. Low public investments of LSGs in Republic of Serbia can be explained by limited decentralization of revenues, by the weak local-level public finance policy, and lack of capacities to plan and deliver infrastructure projects.

Although ithas been argued that fiscal decentralization on the revenue side is needed in order to foster local level public investment, the data (Figure 7 and 8) show that providing additional funding is not likely to result in the rise in public investment, without change in the institutional arrangement and capacities and introduction of systemic incentives. Without introduction of link between revenue allocation and the structure of LSG spending (e.g. by means of the pro-growth incentives and well-defined performance indicators), there is a risk revenue decentralization will be used to finance expenditures items that yield

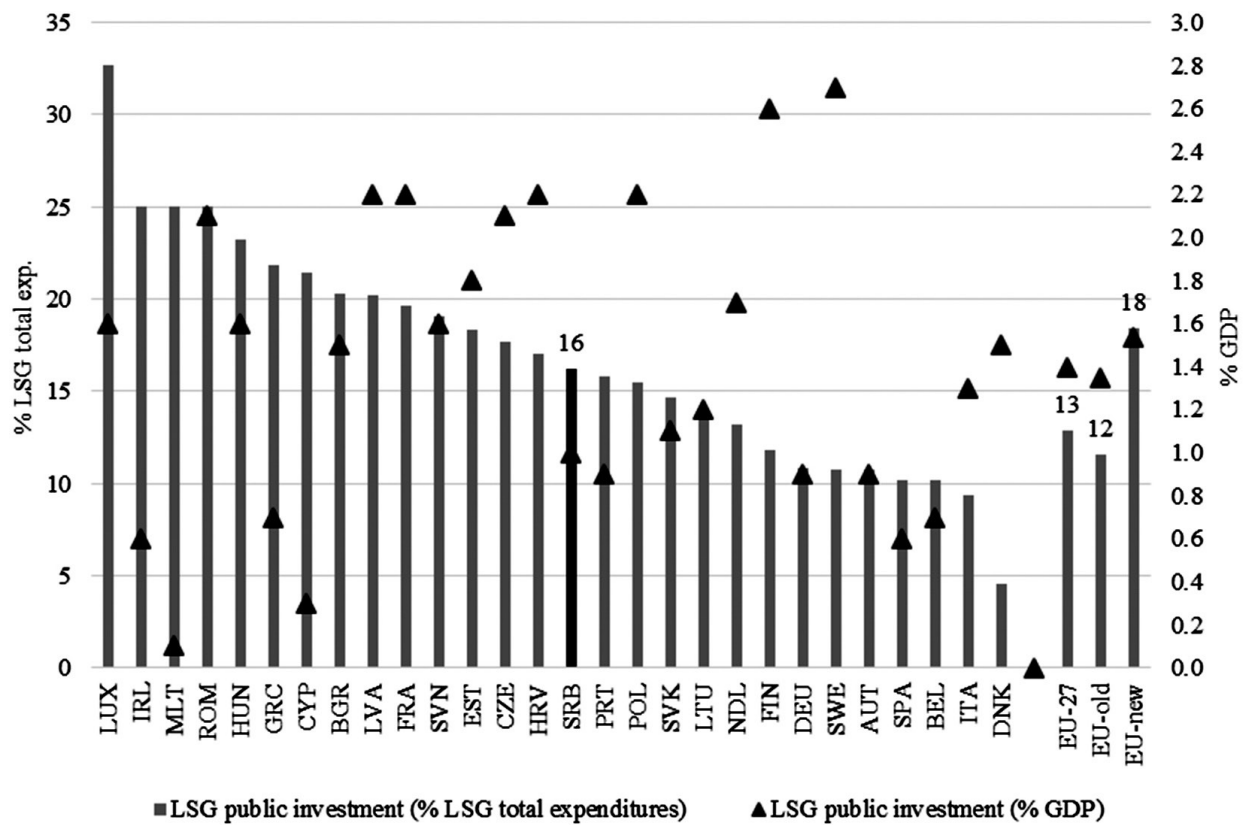

Figure 8 LSG public investment in 2019: Republic of Serbia versus Europe 
short-run political dividend, rather than focusing on development of prerequisites for the long-run growth. This is illustrated by the declining share of LSG public investment in the total expenditures of LSG from $22 \%$ in 2010 to 16\% in 2019 (Figure 9).

Analysis based on 2018 micro data for 27 sample LSGs also indicates strong variation in the relative amount of public investment across LSGs (Figure 10). The average share of public investment in the total expenditures stood at $13.7 \%$, with the coefficient of variation equals $44.6 \%$. Large variation in the local public investment may be caused by the lack of the systemic link between the LSG financing instruments and LSG's expenditure policy. However, the sample LSG data indicate that on average execution of public investment is lower by $20 \%$ than the amount disclosed in the projected annual budget while very close to collected revenues. This indicates that LSGs in general are systematically overestimating budgets to compensate for uncertainty in revenue collection and unforeseen efficiency in terms of project management.

Data on 27 sample LSGs also indicate that the LSG public investments are mostly focused on community development (29\%) $)^{\mathrm{iii}}$ and traditional street reconstruction and maintenance (26.9\%). Investments in education, culture and sports infrastructure account for close to $13 \%$, while investments in green infrastructure (environment, waste management, water supply and water waste management) account for less than $6 \%$ of the total local governments' public investment (Figure 11). On the other hand, large chunk of public investment of LSGs (18.9\%) goes to acquisition and development of the other types of infrastructure, required for provision of administrative and general services.

Considering relatively low quality of local level roads infrastructure, lack of appropriate waste management, water supply or waste water management system and low quality of air, it would be expected to see higher share of investment in these types of infrastructure, in the overall amount of capital expenditures. Presented data may suggest that it is not the case, inter alia due to a lack of systemic framework that would foster productive investment and potentially contribute to reconstruction and maintenance of critical infrastructure. Government of Republic of Serbia has

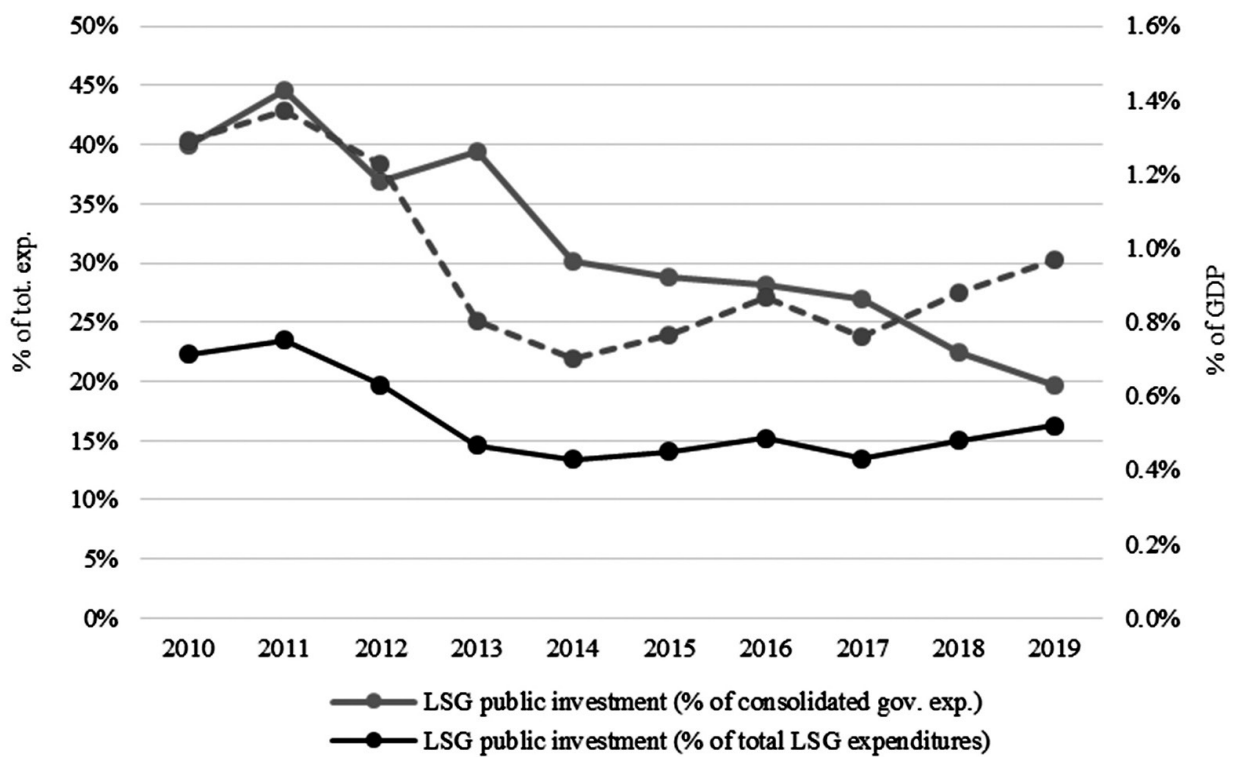

Figure 9 LSG public investment trends 
announced long-term public investment plan "Serbia $2025^{\prime \prime}$, in which investment in local infrastructure is seen as one of the priorities. Considering that it is the role of LSG to invest and maintain communal infrastructure, it may be advised to use the investment plan to introduce systemic incentives for LSGs to increase their efforts in developing and rehabilitating long neglected local infrastructure, rather than having the central government directly engaged in development of communal infrastructure. Having a clear plan and targets should revert from supply to demand driven mindset and enable LSGs to plan on medium and long term.

\section{LOCAL SELF-GOVERNMENTS' FISCAL BALANCE}

According to the Budget System Law (2009), LSG may run fiscal deficit only for the purpose of financing local public investment. Fiscal deficit of local selfgovernment, however cannot be higher than 10\% of its public revenues in the respective year. In case of implementation of large investment project, a LSG may request from the Ministry of Finance a permission to run fiscal deficit higher than this limit, while the decision of the Ministry of Finance shall depend on justification of the request and the general fiscal framework.

LSG deficit may be financed by means of lending. Art 33 of the Law on Public Debt (2005) allows LSGs to borrow money at the market, with a written consent of the Ministry of Finance. The total debt raised to fund current liquidity cannot exceed $5 \%$ of its total revenues in the last year. On the other hand, longterm borrowing is allowed only for the purpose of financing public investment project or repayment of debts, with the following limits:

- long-term debt may not exceed $50 \%$ of budget of LSG in the previous year;

- expenditures for payment of interest and repayment of debt may not exceed $15 \%$ of current revenues of LSG in the respective year.

LSGs are not allowed to issue guarantees. The LSG

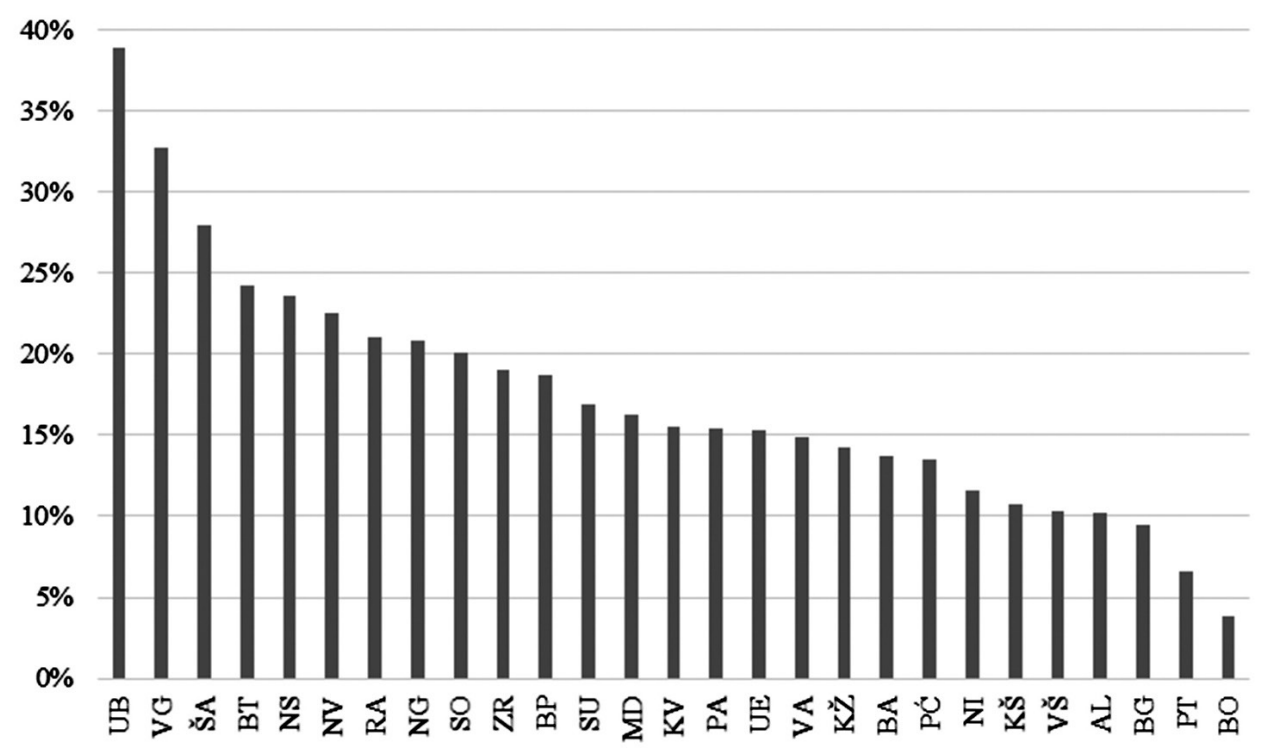

Figure 10 Share of public investment in the total local expenditures, by LSGs (\%) 
fiscal rules set out by the Budget System Law (2009) are in line with the debt issuance provisions, provided by the Law on Public Debt (2005).

In the last decade (2020-2019) LSGs in Republic of Serbia have mostly been running fiscal surplus, while deficit has been posted only in 2012, 2013 and 2019. The average fiscal balance of LSGs in Republic of Serbia from 2010 to 2019 was close to RSD 5.5 bn (surplus), which is equivalent to $2.8 \%$ of their total revenues (Figure 12). This is considerably below the deficit ceiling ( $10 \%$ of public revenues), as set out by the Budget System Law (2009). Over the same timeline, the total expenditures for payment of interest and outlays related to repayment of debt in LSGs in Republic of Serbia amounted to RSD 12 bn (close to EUR 100 million) per year, which was equivalent to $5.5-6 \%$ of their revenues, thus also being far below the statutory limit (15\% of revenues).

\section{CONCLUSION}

Empirical studies show that in the last two decades LSGs in Republic of Serbia posted convergence within two clusters, while Belgrade district shows no signs of convergence with any of the other clubs (Barrios et al, 2020). In spite of the club-convergence, there are still substantial local and regional disparities, which foster migrations of productive population towards more developed regions, thus undermining the convergence chances of underdeveloped areas. Results of empirical studies show that even relatively small changes in economic inequalities can have large effects on migration volumes (Denett, 2014). In this paper, we have evaluated the degree of fiscal decentralization in Republic of Serbia and features of local public finance policies, with the focus on locallevel public investment policy, as strategic, green and growth oriented development of local infrastructure is one of the key reconditions for economic development.

Our results presented in this paper, imply several scientific and practical insights. First, it is concluded that LSGs in Republic of Serbia are rather sizeable, especially in terms of mean population, in comparison with the European practice. Second, the degree of fiscal decentralization in Republic of Serbia is below the European average. LSG public revenues and expenditures (relative to GDP) in Republic of Serbia

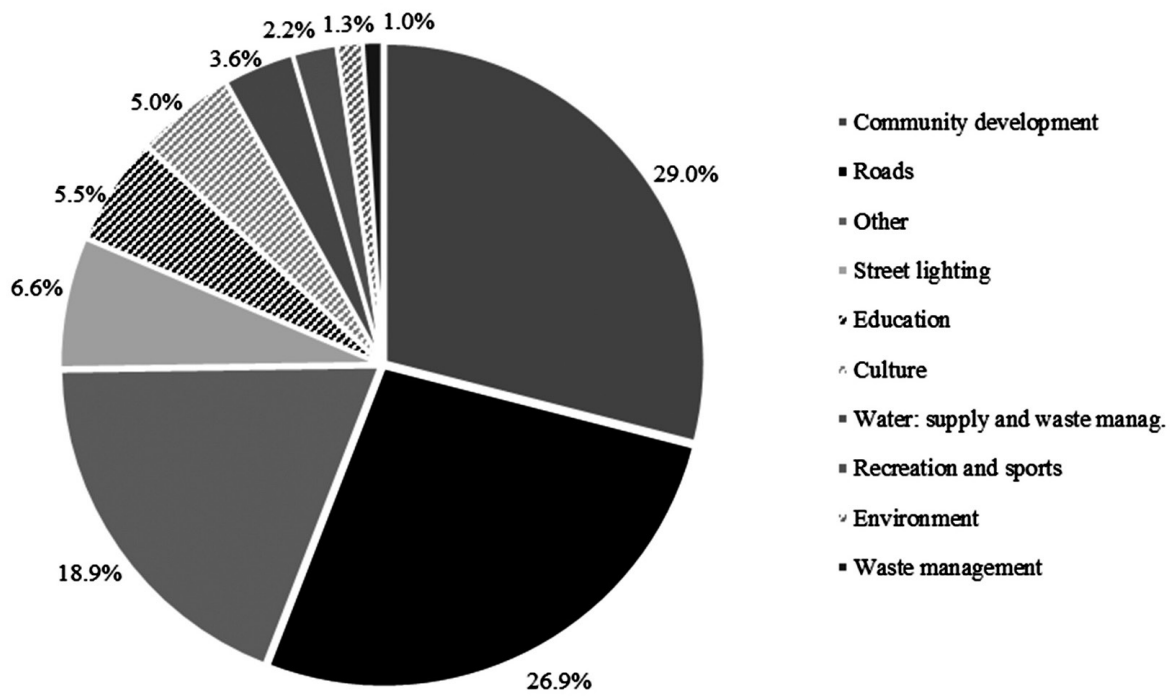

Figure 11 Structure of LSG public investment (\%) 
are lower than the EU and CEE average. Three largest revenue raising instruments for LSGs are personal income tax, property taxes and grants from the central government, accounting for almost $3 / 4$ of the total revenues. More than half of LSG revenues are assigned or transferred by the central governments, indicating low degree of fiscal autonomy. Third, mentioned indicators show that local public investments in the Republic of Serbia have been low, while their variation across LSGS was high. Thus, on the spending side, the main items are purchase of goods and services and wages, accounting for $55 \%$ of total expenditures, while the share of public investment in total LSG outlays is yet $16 \%$ (i.e. one fifth of the consolidated government public investment). Relative size of LSG public investment in Republic of Serbia ( $1 \%$ of GDP) is considerably below the CEE average (1.4\% of GDP). Fourth, decentralization of public revenues, implemented at the beginning of last decade has not led to rise in local public investments, which have been on decline for long time. Fifth, LSG public investment in Republic of Serbia are mostly oriented to community development and traditional streets reconstruction and maintenance, while investment in education, culture and sports infrastructure as well as in environmental infrastructure are rather low. In spite of rise in the total revenues (e.g. wage tax revenue decentralization) over the last decade, LSG public investment posted a real decline. Sixth, the fact that a significant number of LSGs had low public investments even in periods when they were running a budget surplus indicates that in addition to fiscal constraints, some of them also face limitations in terms of their capacity for planning and implementation of investment projects. The low level of local public investment and the fact that it has not increased even when revenues have risen, signal that LSGs lack mid and long term planning capacities and that institutional design of LSG financing system lacks systematic incentives for pro-growth investment local public finance policy and clear performance indicators. This is because the amount of revenues that local governments generate, as well as the grants they receive from the central government, do not depend on the quality and efficiency of their fiscal policy. Recent changes to planning legislation, requiring preparation of development plans (7 years) and mid term plans (3 years) could be an anchor to improve planning capacities provided properly prepared and monitored.

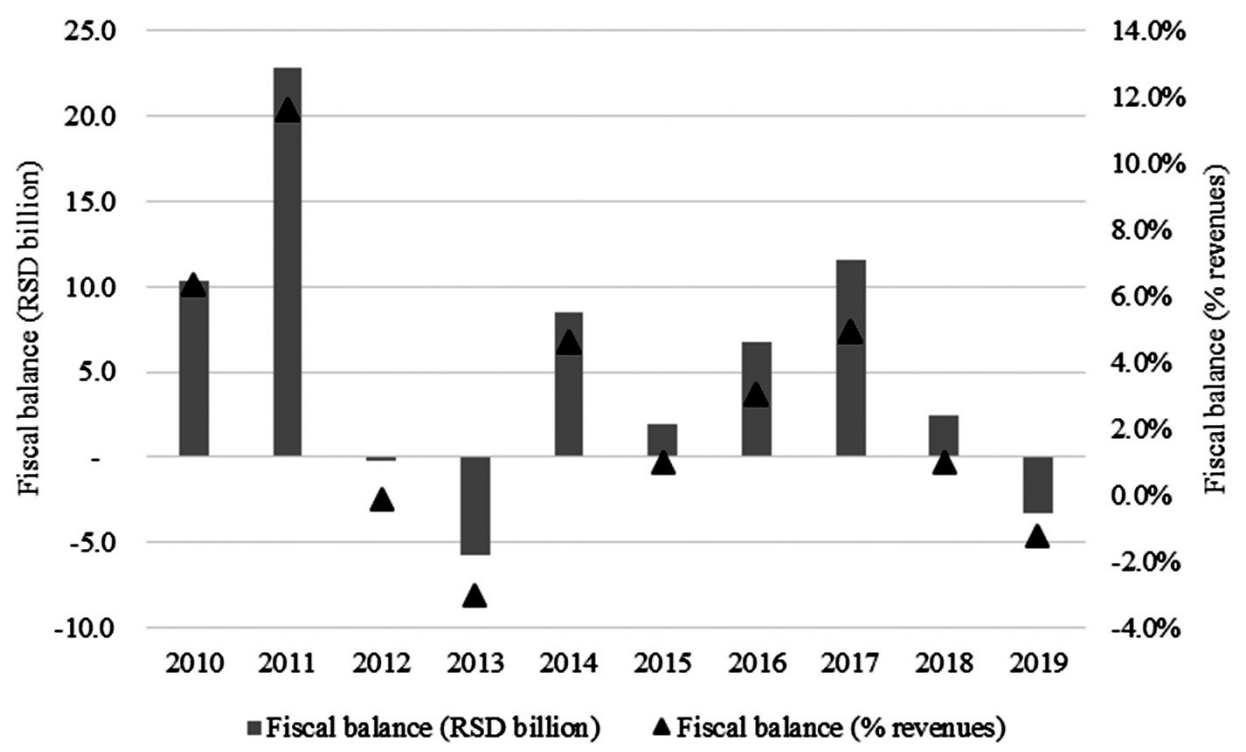

Figure 12 LSG fiscal balance dynamics, 2010-2019 
Lessons from comparative (international) practice suggest that for a more permanent and sustainable increase in the local growth and green oriented public investments introduction of systemic incentives can be effective. Those are the incentives that reward LSGs, which direct more of their public expenditures to productive purposes. In addition to that, systemic approach to public administration reform that would result in improvement of their administrative, technical, and planning capacities, may also contribute to enhancement of the overall efficiency of local public investment policy.

According to the above mentioned, the scientific relevance of the obtained results refers to the evaluation of the relationship between fiscal decentralization and public investment, and especially to the relationship between the dynamics of public revenues and the amount of local public investment, in the absence of systemic incentives for investment. In addition, the obtained results provide relevant insights for policy makers, since the paper, in addition to analysing the situation, identifies the causes of low local public investment, as well as key institutional barriers to their increase. The analysis in this paper is based on the methods of descriptive statistical analysis. To provide additional robust insights into the relationship between the level of fiscal decentralization and the level of local public investment, it would be necessary to apply relevant methods of econometric analysis, in order to control for the impact of other factors. In addition to the relationship between fiscal decentralization and local public investment, the issue of the impact of the level and structure of local public investment on local economic development is relevant, which may be an interesting issue for further research.

\section{ENDNOTES}

i As economic and fiscal trends in 2020 may have been affected by extraordinary processes caused by the COVID-19 pandemic, discussion of structural characteristics of local public finance policy based on 2020 data may be misleading, which is why the sample is restricted to the period until 2019. The data on Serbia, disclosed in this study refer to the territory of the Republic of Serbia without Kosovo and Metohija*, as according to the UN Security Council Resolution 1244 it is formally the area under administration of the UN since 1999.

ii Data are related to the year 2019. Data on expenditure per capita, per LSG, presented in the Figure 10, are related to the year 2018, which is the latest year for which expenditure data per municipality are available.

iii According to the official COFOG classification, Community Development includes: administration of community development affairs and services - administration of zoning laws and land-use and building regulations, planning of new communities or of rehabilitated communities, planning the improvement and development of facilities such as housing, industry, public utilities, health, education, culture, recreation, etc. for communities; preparation of schemes for financing planned developments; production and dissemination of general information, technical documentation and statistics on community development affairs and services.

\section{REFERENCES}

Akai, N., \& Sakata, M. (2002). Fiscal decentralization contributes to economic growth: Evidence from state-level cross-section data for the United States. Journal of urban economics, 52(1), 93108. doi.org/10.1016/S0094-1190(02)00018-9

Aristovnik, A. (2012). Fiscal Descentralization in Eastern Europe: Trends and selected issues. Transylvanian Review of Administrative Sciences, 8(37), 5-22. doi:10.2139/ssrn.2187475

Arsić, M., Ranđelović, S., Bućić, A.i Vasiljević, D. (2012). Reforme poreza na imovinu u Srbiji: Rezultati i perspektive. Beograd, RS: Univerzitet u Beogradu - Ekonomski fakultet, Fondacija za razvoj ekonomske nauke.

Arsić, M., Ranđelović, S. i Nojković, A. (2019). Uzroci i posledice niskih investicija u Srbiji. U M. Zec i O. Radonjić (Ur.). Ekonomska politika Srbije u 2019. godini (str. 63-84). Beograd, RS: Univerzitet u Beogradu - Ekonomski fakultet. 
Barrios, M. C., Jandrić, M., Molnar, D., \& Tanasković, S. (2021). Convergence clubs in different regions of Serbia. Applied Economics Letters, 28(7), 594-598. doi.org/10.1080/13504851.2 020.1765960

Baskaran, T., \& Feld, L. P. (2013). Fiscal decentralization and economic growth in OECD countries: Is there a relationship? Public finance review, 41(4), 421-445. doi.org/10.1177/1091142112463726

Bird, R. M. (2000). Intergovernmental fiscal relations: Universal principals, local applications. Working Paper 00-2, Georgia State University, Andrew Young School of Policy Studies, Atlanta.

Bodman, P. (2011). Fiscal decentralization and economic growth in the OECD. Applied Economics, 43(23), 3021-3035. doi.org/10.1080/00036840903427208

Dennett, A. (2014). Quantifying the effects of economic and labour market inequalities on inter-regional migration in Europe-a policy perspective. Applied Spatial Analysis and Policy, 7(1), 97-117. doi:10.1007/s12061-013-9097-4

Dziobek, C. H., Mangas, C. A. G., \& Kufa, P. (2011). Measuring fiscal decentralization: Exploring the IMF's databases. IMF Working Papers, 11(126).

Martinez-Vazquez, J., \& McNab, R. M. (2003). Fiscal decentralization and economic growth. World development, 31(9), 1597-1616. doi.org/10.1016/S0305750X(03)00109-8

Molnar, D. (2014). Fiskalna decentralizacija i privredni rast: Evropska unija i Srbija. Reforme i razvoj, 73.

Oates, W. E. (1972). Fiscal Federalism. New York, NY: Harcourt Brace Jovanovich

Petrović, P., Arsić, M., \& Nojković, A. (2021). Increasing public investment can be an effective policy in bad times: Evidence from emerging EU economies. Economic Modelling, 94, 580597. doi:10.1016/j.econmod.2020.02.004

Ministarstvo finansija. (2020). Public Finance Bulletin No. 12/2020. Ministry of Finance of the Republic of Serbia, Belgrade. Retrieved Marc 14. 2021. from: https://www.mfin. gov.rs//upload/media/K1WfqN_6042278628737.pdf
Ranđelović, S. (2020). Pro-growth public investment policy in Serbia: Sufficiency and efficiency. Ekonomika preduzeća, 68(12), 137-146. doi:10.5937/EKOPRE2002137R

Ranđelović, S. (2021). Determinants of volatility of economic activity in Europe during the Covid-19 pandemic: Stylized facts. Ekonomika preduzeća, 69(3-4), 231-242. doi:10.5937/ EKOPRE2103231R

Rosen, H. S., \& Gayer, T. (2014). Public Finance, $10^{\text {th }}$ edition. New York, NY: McGraw-Hill Irwin.

Stansel, D. (2005). Local decentralization and local economic growth: A cross-sectional examination of US metropolitan areas. Journal of Urban Economics, 57(1), 55-72. doi:10.1016/j. jue.2004.08.002

Stigler, G. (1957). The Tenable Range of Functions of Local Government. In Federal Expenditure Policy for Economic Growth and Stability (pp. 213-219). US Congress Joint Economic Committee, Government Printing Office, Washington, DC.

Tiebout, C. M. (1956). A Pure Theory of Public Expenditures". Journal of political economy, 64(5), 416-424.

Zakon o budžetskom sistemu. (2009). Sl. glasnik RS, br. 54/2009, 73/2010, 101/2010, 101/2011, 93/2012, 62/2013, 63/2013 - ispr., 108/2013, 142/2014, 68/2015 - dr. zakon, 103/2015, 99/2016, 113/2017, 95/2018, 31/2019, 72/2019 i 149/2020).

Zakon o finansiranju lokalne samouprave. (2006). Sl. glasnik RS, br. 62/2006, 47/2011, 93/2012, 99/2013 - usklađeni din. izn., 125/2014 - usklađeni din. izn., 95/2015 - usklađeni din. izn., 83/2016, 91/2016 - usklađeni din. izn., 104/2016 - dr. zakon, 96/2017 - usklađeni din. izn., 89/2018 - usklađeni din. izn., 95/2018 - dr. zakon, 86/2019 - usklađeni din. izn. i 126/2020 - usklađeni din. izn.)

Zakon o javnom dugu. (2005). Sl. glasnik RS, br. 61/2005, 107/2009, 78/2011, 68/2015, 95/2018, 91/2019 i 149/2020).

Zakon o lokalnoj samoupravi. (2007). Sl. glasnik RS, br. 129/2007, 83/2014 - dr. zakon, 101/2016 - dr. zakon i 47/2018).

Zakon o teritorijalnoj organizaciji Republike Srbije. (2007). SI. glasnik RS, br. 129/2007, 18/2016, 47/2018 i 9/2020 - dr. Zakon). 
Received on $9^{\text {th }}$ Jun 2021, after revision, accepted for publication on $25^{\text {th }}$ November 2021. Published online on $6^{\text {th }}$ December 2021.

Sasa Randjelovic is associate professor at the University of Belgrade, Faculty of Economics (Department of Economic Policy and Development). He holds PhD in economics from the University of Belgrade. His field of research includes public finance and fiscal policy.

Svetlana Vukanovic is a Senior Transport Specialist at the World Bank. She has been leading a number of infrastructure project across Western Balkans. Svetlana holds a PhD from the Munich University of Technology, and MSc from the Faculty of Organizational Science at the University of Belgrade. 


\title{
FISKALNA DECENTRALIZACIJA I LOKALNA POLITIKA JAVNIH INVESTICIJA U REPUBLICI SRBIJI
}

\author{
Saša Ranđelovićíc ${ }^{*}$ i Svetlana Vukanović ${ }^{2}$ \\ ${ }^{1}$ Ekonomski fakultet Univerziteta u Beogradu \\ ${ }^{2}$ Svetska banka, Beograd, Republika Srbija
}

U ovom radu se analizira nivo fiskalne decentralizacije i strukturne karakteristike lokalnih javnih finansija u Republici Srbiji, sa fokusom na lokalnu politiku javnih investicija. Udeo rashoda centralnog nivoa vlasti u konsolidovanim javnim rashodima u Republici Srbiji iznosi 83\%, što ukazuje na relativno visok stepen fiskalne centralizacije. I pored rasta javnih prihoda u poslednjoj deceniji, lokalne javne investicije su i dalje niske - u Republici Srbiji iznose 1\% BDP-a, što je znatno ispod proseka EU $(1,4 \%)$ i Centralne i Istočne Evrope (1,5\% BDP-a). Rezultati ukazuju na velike razlike u relativnoj visini javnih investicija po lokalnim samoupravama. Veći deo lokalnih javnih investicija usredsređen je na održavanje putne i administrativne infrastrukture, dok su ulaganja u životnu sredinu i obrazovanje niska. Da bi se smanjili lokalni dispariteti u kvalitetu lokalne infrastrukture i podstakla ekonomska konvergencija, neophodno je unapređenje kapaciteta za planiranje i sprovođenje investicija i uvođenje sistemskih podsticaja za lokalne javne investicije.

Ključne reči: fiskalna decentralizacija, lokalna samouprava, javne finansije, javne investicije na lokalnom nivou

JEL Classification: H70, H71, H72, H74

\section{UVOD}

Teritorijalno i političko uređenje države određeno je, u velikoj meri, načinom na koji je formirana, njenim kulturnim nasleđem, kao i društvenopolitičkim i ekonomskim karakteristikama društva. $\mathrm{S}$ tim u vezi, jedno od relevantnih pitanja u domenu fiskalnog federalizma odnosi se na optimalan

* Korespondencija: S. Ranđelović, Ekonomski fakultet Univerziteta u Beogradu, Kamenička 6, 11000 Beograd, Republika Srbija; e-mail: sasa.randjelovic@ekof.bg.ac.rs nivo raspodele funkcija i resursa po nivoima vlasti i uticaj intenziteta fiskalne decentralizacije na ukupne ekonomske performanse države, pre svega, na dugoročni ekonomski rast. Osim u evropskim tranzicionim ekonomijama, nivoi decentralizacije su tokom vremena bili relativno stabilni, pri čemu je prikupljanje prihoda relativno više centralizovano od politike javnih rashoda (Dziobek, Mangas \& Kufa, 2011). Teorijski argumenti u prilog fiskalnoj decentralizaciji zasnivaju se na, takozvanom, Tibuovom modelu, koji sugeriše da postojanje više 
političkih jedinica (lokalnih samouprava) omogućava ljudima da se presele kako bi izabrali onu koja najbolje odražava njihove preferencije, u smislu kvaliteta lokalnih javnih dobara i usluga i visine i strukture poreza (Tiebaut, 1956). Stoga se smatra da postojanje većeg broja lokalnih samouprava omogućava prilagođavanje njihovih politika preferencijama njihovih stanovnika, što pozitivno utiče na ukupno društveno blagostanje (Stigler, 1957). To bi ukazalo da fiskalna konkurencija između lokalnih samouprava dovodi do efikasne alokacije resursa, što pozitivno utiče na ukupnu ekonomsku efikasnost (Oates, 1972). Ovi teorijski stavovi potkrepljeni su i empirijskim istraživanjima koja pokazuju da postojanje većeg broja lokalnih samouprava na 100.000 stanovnika pozitivno utiče na lokalni ekonomski razvoj (Akai \& Sakata, 2002; Stansel, 2005). S druge strane, postoji i relativno veliki broj empirijskih istraživanja koja sugerišu postojanje negativne veze između fiskalne decentralizacije i ekonomskog rasta (MartinezVazkues \& McNab, 2003; Bodman, 2011; Baskaran \& Feld, 2013).

Rezultati teorijskih i empirijskih analiza, takođe, ukazuju da veza između fiskalne decentralizacije i ekonomskog rasta nije linearna, već da zavisi od stepena decentralizacije, transparentnosti javnih finansija, dizajna podsticaja kreiranih sistemom finansiranja i efikasnosti korišćenja javnih resursa na sub-centralnim nivoima vlasti (Bird, 2000). Novija empirijska istraživanja ukazuju da je jedan od glavnih razloga relativno sporog rasta privrede Republike Srbije (RS) u poslednje dve decenije (u poređenju sa rastom koji su, na primer, ostvarile azijske zemlje kada su bile na istom nivou razvoja), nizak nivo investicija, pre svega, javnih investicija, kao i domaćih privatnih investicija (Arsić, Ranđelović i Nojković, 2019). Nedovoljan nivo konsolidovanih državnih javnih investicija posledica je niskih ulaganja kako centralnog, tako i lokalnog nivoa države. Ipak, u poslednjih nekoliko godina, javne investicije na centralnom nivou države znatno su porasle, dok su lokalne javne investicije ostale relativno niske, uprkos dodatnoj decentralizaciji javnih prihoda (Ranđelović, 2020). Uzimajući u obzir da empirijska istraživanja pokazuju da su fiskalni multiplikatori povezani sa javnim ulaganjima $\mathrm{u}$ evropskim ekonomijama $\mathrm{u}$ razvoju relativno visoki (Petrović, Arsić \& Nojković, 2021), niska javna ulaganja izazivaju značajne gubitke u smislu propuštenog budućeg ekonomskog rasta. Zbog toga je, u cilju podsticanja dugoročnog ekonomskog rasta, pored brojnih drugih preduslova, potrebno poboljšati institucionalne mehanizme koji bi obezbedili relativno visok nivo javnih investicija na svim nivoima države, čija bi primena bila transparentna i efikasan.

Predmet istraživanja $u$ ovom radu je stanje fiskalne decentralizacije u Republici Srbiji, kao i analiza performansi sistema finansiranja lokalnih samouprava i karakteristika lokalne politike javne potrošnje, sa fokusom na javne investicije.

Shodno tome, u radu se testiraju dve hipoteze:

H1: Nivo lokalnih javnih investicija u Republici Srbiji je nizak.

H2: Decentralizacija prihoda, bez uvođenja sistemskih podsticaja, ne dovodi do automatskog povećanja lokalnih javnih investicija.

Svrha ovih razmatranja je pružanje utemeljene ocene karakteristika institucionalnog uređenja vezanog za finansiranje lokalne samouprave (LSU) u RS i identifikacija područja za unapređenje mehanizama finansiranja LSU, usmerenih na promociju lokalne politike javnih investicija i podsticanje lokalnog ekonomskog razvoja. Analiza u ovom radu zasniva se na primeni metoda deskriptivne statističke analize agregatnih (makroekonomskih) podataka, dostupnih u Biltenu javnih finansija za period 2010-2019i. Procena varijacija u strukturnim karakteristikama lokalne politike javnih finansija vrši se korišćenjem podataka na nivou LSU, za 27 gradova i opština u uzorku, za koje su autori prikupili podatke o realizaciji budžeta. Uzorci LSU čine 52\% ukupnog stanovništva u RS, 59\% ukupnih izdataka LSU i 62\% ukupnih prihoda LSU.

Ostatak rada strukturiran je na sledeći način. Odeljak 2 pruža uvid u ključne činjenice o teritorijalnoj organizaciji i fiskalnoj decentralizaciji u RS. U odeljku 3 analiziraju se karakteristike i performanse instrumenata finansiranja LSU, dok se odeljak 4 bavi analizom stanja, strukture i dinamike politike 
javnih rashoda LSU, sa posebnim fokusom na lokalnu politiku javnih investicija. U odeljku 5, ocenjuju se karakteristike i performanse institucionalnog okvira $\mathrm{u}$ domenu fiskalnog bilansa i duga LSU, dok su $\mathrm{u}$ odeljku 6 data zaključna razmatranja.

\section{TERITORIJALNA ORGANIZACIJA I FISKALNA DECENTRALIZACIJA U REPUBLICI SRBIJI}

Republika Srbija je organizovana kao unitarna država, sa dominantnim nivoom centralnog nivoa vlasti, te sub-centralnim nivoom vlasti koji se sastoji od lokalnih samouprava i autonomnih pokrajina. Lokalne samouprave mogu imati oblik opština (obično iznad 10.000 tanovnika) i gradova (sa više od 100.000 stanovnika). Ova ograničenja za formiranje opština i gradova mogu se ublažiti iz ekonomskih, geografskih $\mathrm{i}$ istorijskih razloga, što znači da se opštine i gradovi mogu formirati čak i ako je ukupan broj stanovnika manji od 10.000 odnosno, 100.000. Prema Zakonu o teritorijalnoj organizaciji Republike Srbije (2007), njena teritorija se sastoji od 145 lokalnih samouprava: 117 opština, 27 gradova i glavni grad (Beograd). Pored toga, u RS postoje 24 okruga, koji su definisani kao administrativne jedinice, bez efektivnih funkcija i budžeta.

Prosečan broj stanovnika po LSU u RS iznosi blizu 48 hiljada, što je za $37 \%$ više od proseka Evropske unije (EU) ili Zapadnog Balkana (ZB). S druge strane, prosečna površina LSU u Republici Srbiji iznosi 534 $\mathrm{km}^{2}$, što je blizu proseka EU i nešto više od proseka ZB (Slika 1). Ovi podaci ukazuju na to da su lokalne samouprave u RS prilično velike, posebno u pogledu broja stanovnika, u poređenju sa evropskom praksom.

Teritorijalna organizacija može, donekle, oblikovati fiskalnu decentralizaciju zemlje. Fiskalna decentralizacija se može meriti na različite načine, pri čemu je jedan od često korišćenih pokazatelja koeficijent centralizacije, koji meri udeo rashoda centralnog nivoa države $u$ konsolidovanim rashodima države (Rosen \& Gayer, 2014). Zbog

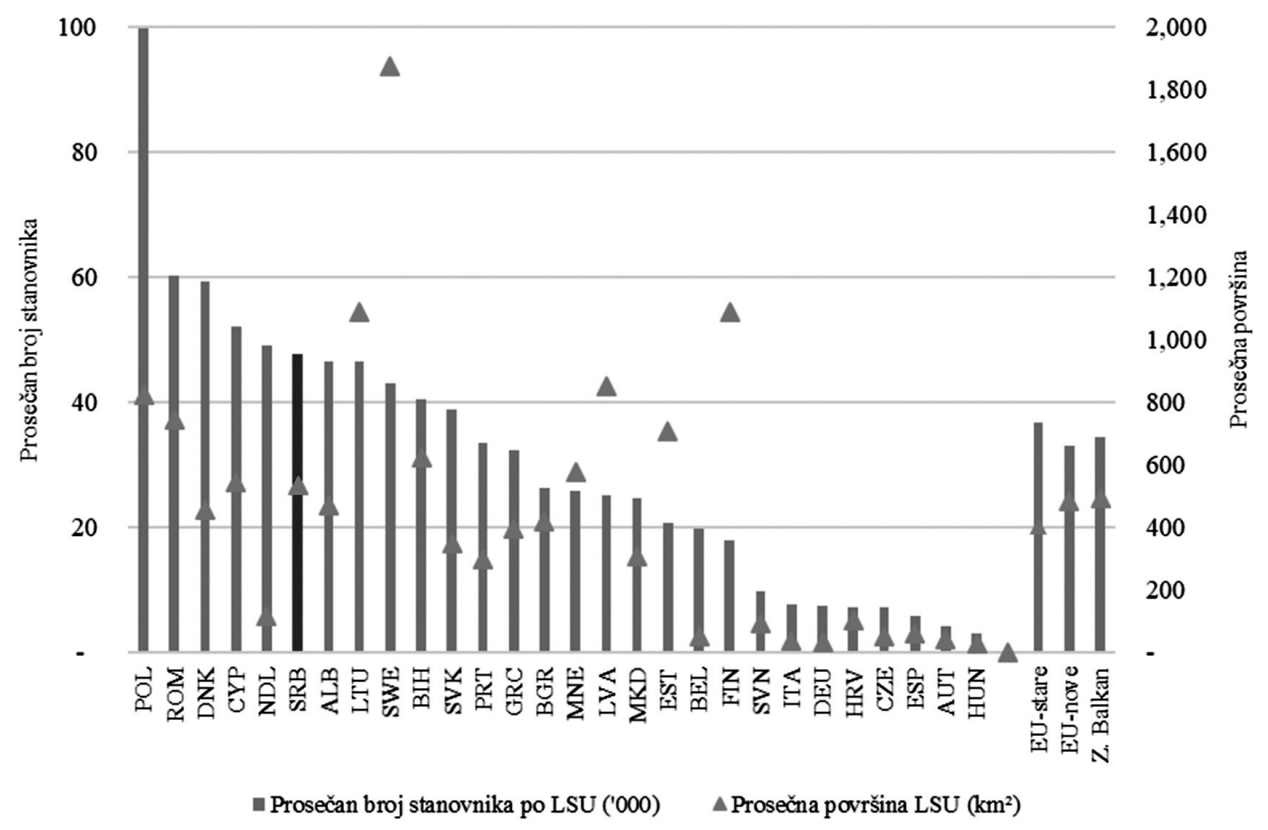

Slika 1 Prosečan broj stanovnika po LSU ('000) i prosečna površina LSU ( $\left.\mathrm{km}^{2}\right)$ u Evropi 
unitarnog karaktera države, 83\% konsolidovanih državnih rashoda u RS realizuje se na nivou centralne države (budžet Republike Srbije, fondovi socijalnog osiguranja i slično), što je iznad proseka EU-27 i Zapadnog Balkana (Slika 2). Podaci, predstavljeni na Slici 2, sugerišu postojanje većeg nivoa fiskalne decentralizacije u razvijenim evropskim zemljama nego u evropskim zemljama u razvoju. To je u skladu sa nalazima drugih empirijskih studija, zasnovanih na sofisticiranijoj metodologiji, koja uzima u obzir ne samo raspodelu budžeta po nivoima vlasti, već i efektivnu fiskalnu autonomiju, u pogledu funkcija i ovlašćenja (Aristovnik, 2012; Molnar, 2014).

\section{FINANSIRANJE LOKALNIH SAMOUPRAVA}

\section{Institucionalni okvir}

Finansiranje LSU u RS regulisano je Zakonom o finansiranju lokalne samouprave (2006). U skladu sa Članom 2 tog zakona, postoje tri grupe instrumenata finansiranja LSU: izvorni prihodi, ustupljeni prihodi, i transferi centralnog nivoa države. Izvorni prihodi su instrumenti za prikupljanje prihoda koje definiše, uvodi i prikuplja lokalna samouprava, što znači da je lokalna samouprava relativno slobodna da odlučuje o njihovim karakteristikama, parametrima i iznosima. To su: periodični porez na imovinu, lokalni administrativni i komunalni porezi, boravišne takse, neke naknade za korišćenje javnih dobara, koncesione naknade, neke novčane kazne, prihodi od zakupa imovine u vlasništvu LSU, samodoprinosi, grantovi itd. Ustupljeni prihodi obuhvataju instrumente javnih prihoda koje je definisala, uvela i prikupila centralna država, a zatim ih dodelila LSU na osnovu zakonskih kriterijuma. Postoji nekoliko vrsta ustupljenih prihoda: $74 \%$ prihoda od poreza na zarade, pun iznos ostalih poreza na dohodak građana, porez na nasledstvo i poklone i porez na prenos apsolutnih prava.

Bespovratna sredstva centralnog nivoa vlasti su transferi obezbeđeni iz budžeta Republike u budžete lokalnih samouprava, $\mathrm{u}$ obliku nenamenskih i

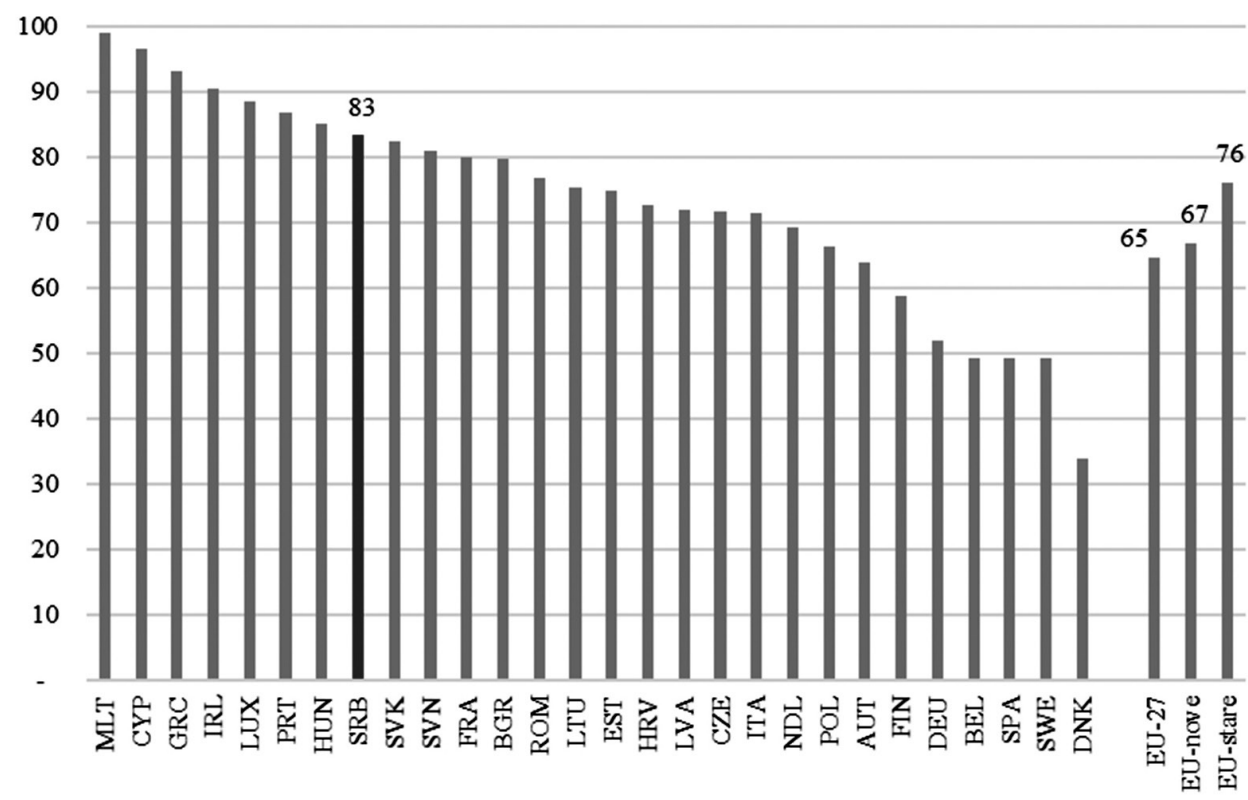

Slika 2 Koeficijent centralizacije u Evropi (\%) 
namenskih transfera. Nenamenski transferi se dele na: transfer za ujednačavanje, opšti transfer, kompenzacioni transfer i transfer solidarnosti. Ukupan iznos nenamenskih transfera utvrđen je Zakonom o finansiranju lokalne samouprave (2006), na nivou 1,7\% BDP-a. Ovaj iznos se koristi, prvenstveno, za finansiranje transfera za ujednačavanje, koji imaju za cilj da pomognu lokalnim samoupravama, koje imaju lošiji učinak u smislu naplate prihoda, zbog nerazvijenosti. Transferi za ujednačavanje se isplaćuju jedinicama lokalne samouprave koje imaju ustupljene prihode po glavi stanovnika ispod 90\% proseka ustupljenih prihoda po stanovniku u svim LSU u RS. Kompenzacioni transfer ima za cilj da nadoknadi prihode koje su LSU izgubile usled promene poreskog zakonodavstva od strane centralnog nivoa vlasti. Ovaj transfer bi trebalo da nadoknadi lokalnim samoupravama deo propuštenih (dodeljenih) poreskih prihoda, tako da relativni pad poreskih prihoda centralnog nivoa vlasti i lokalnih samouprava bude jednak. Opšti transfer se dodeljuje svim LSU. Maksimalni iznos opšteg transfera dobija se oduzimanjem transfera za ujednačavanje i kompenzacionih transfera od ukupnog iznosa nenamenskih transfera. Prema Članu 42 Zakona o finansiranju lokalne samouprave (2006), postoji nekoliko kriterijuma na osnovu kojih se izračunava iznos opšteg transfera LSU: broj stanovnika (65\% opšteg transfera), ukupna površina LSU (19,3\%), broj odeljenja u osnovnim školama $(4,56 \%)$, broj osnovnih škola $(1,14 \%)$, broj odeljenja u srednjim školama (2\%), broj srednjih škola $(0,5 \%)$, broj dece u obdaništima (6\%), broj ustanova za brigu o deci $(1,5 \%)$. Iznos transfera za ujednačavanje, kompenzacionih i opštih transfera za svaku LSU koriguje se koeficijentom razvijenosti, koji se kreće od 0,5 do 1, kako bi se zaštitile nerazvijene LSU i podstakao njihov ekonomski rast. Iznos transfera za ujednačavanje, opštih i kompenzacionih transfera, namenjen Gradu Beogradu, koristi se za finansiranje fonda za transfer solidarnosti, koji se isplaćuje ostalim LSU na osnovu njihovog nivoa razvijenosti.

Namenski transferi se dele na funkcionalne transfere i namenske transfere $u$ užem smislu. Funkcionalni transfer ima za cilj da obezbedi sredstva LSU potrebna za finansiranje dodatnih troškova LSU, nastalih zbog prebacivanja funkcija i ovlašćenja sa centralnog nivoa države na LSU. Na sličan način, centralni nivo države može da pruži lokalnim samoupravama namenski transfer u užem smislu, zahtevajući od njih da koriste taj transfer samo za obavljanje određene funkcije, kako je utvrđeno zakonom. Da bi se osigurala transparentnost isplate, podaci o nenamenskim transferima koji se daju svakoj LSU moraju biti objavljeni u Fiskalnoj strategiji. Međutim, u praksi se ovi podaci ne objavljuju redovno.

Opis šeme finansiranja LSU sugeriše da veličina budžeta LSU zavisi od njihove veličine, nivoa razvijenosti, funkcija, karakteristika javnih usluga, itd, dok efikasnost upotrebe sredstava (struktura rashoda) i napori na prikupljanju izvornih prihoda nemaju direktan uticaj na sistem finansiranja LSU. To znači da šema finansiranja LSU ne stvara sistemske (pozitivne) podsticaje u smislu prikupljanja prihoda (iz sopstvenih izvora), kao ni u pogledu produktivne alokacije resursa (Arsić, Ranđelović, Bućić i Vasiljević, 2012).

\section{Fiskalna izdašnost}

Ukupni prihodi LSU u RS (uključujući transfere centralnog nivoa države) u 2019, iznosili su 2,7 milijardi evra, što je ekvivalentno 5,9\% BDP-a. Relativno, prihodi od lokalne samouprave u RS su znatno ispod proseka EU (9,9\% BDP-a). Međutim, kada se uporedi sa novim državama članicama EU iz Centralne i Istočne Evrope (CIE), koje su uporedivije sa RS, razlika je znatno manja (Slika 3). Prihodi LSU u RS čine 14\% konsolidovanih državnih prihoda, što je znatno ispod proseka EU-27 (22\%) i proseka novih zemalja članica EU (20,7\%). Ovo je posledica promena u teritorijalnoj organizaciji kao i vertikalne raspodele funkcija države. Kao rezultat promena u propisima o finansiranju LSU i napora $u$ pogledu prikupljanja prihoda, ukupni prihodi LSU u RS, u 2019, realno su porasli za $15 \%$ u poređenju sa 2010, uglavnom, zbog povećanja poreza na zarade i poreza na imovinu, dok su transferi centralnog nivoa države ostali gotovo nepromenjeni.

Kriza javnog zdravlja, izazvana pandemijom COVID-19, imala je značajan negativan uticaj na 


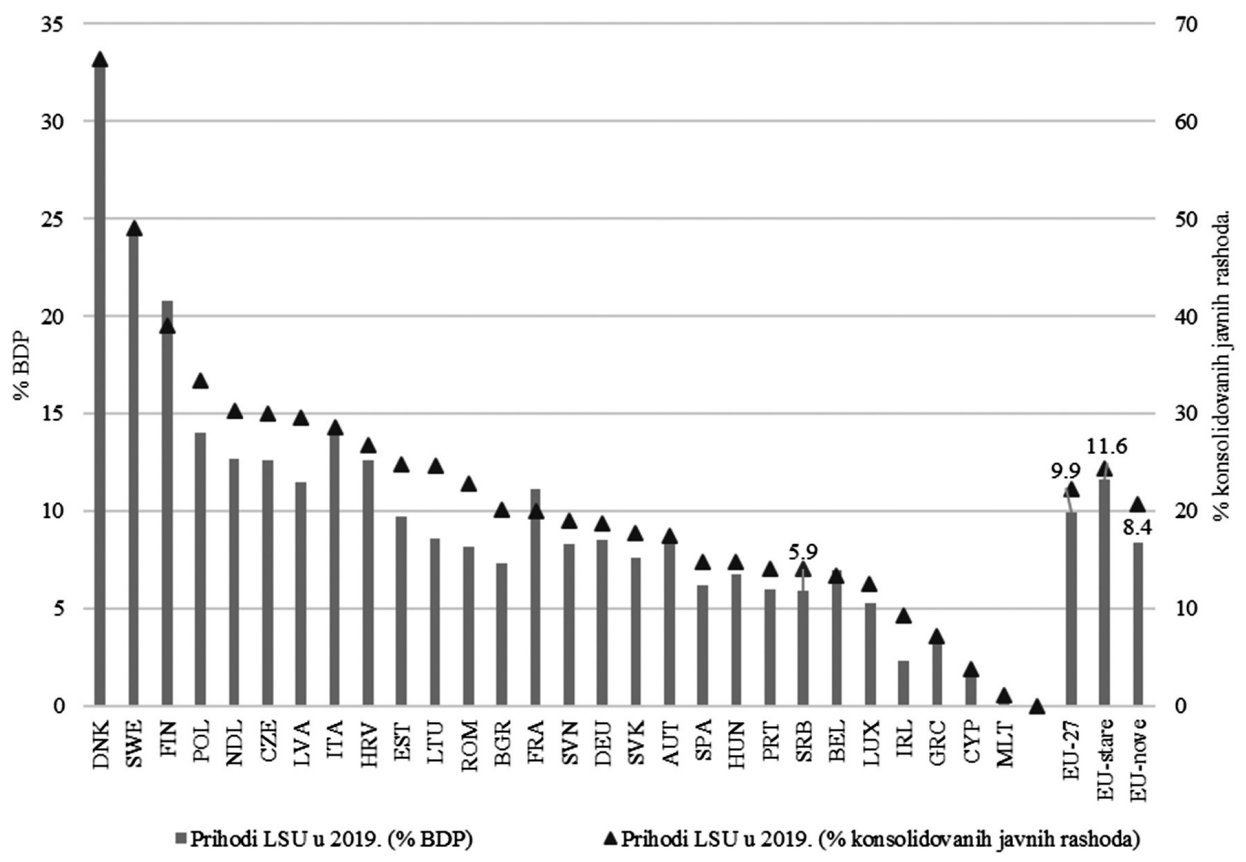

Slika 3 Javni prihodi lokalnih samouprava u Republici Srbiji i Evropi

Izvor: Autori

ekonomske trendove $u$ većem delu sveta. Mnoge zemlje, uključujući i RS, reagovale su putem masovnih fiskalnih podsticaja, koji su uključivali opciju datu privatnom sektoru da odloži plaćanje poreza, što je znatno ublažilo recesiju (Ranđelović, 2021). Međutim, podaci Ministarstva finansija pokazuju da su, u 2020, poreski prihodi LSU u RS beležili blagi nominalni rast (a realno su stagnirali), dok su ukupni prihodi lokalne samouprave zabeležili blagi nominalni pad od 2,8\% (Ministarstvo finansija, 2020). Relativno blagi pad se može pripisati činjenici da veliki deo prihoda LSU dolazi od poreza sa stabilnom poreskom osnovicom (porezi na imovinu). Kako su državne subvencije sprečile masovni rast nezaposlenosti, tako su i prihodi od poreza na zarade bili stabilni. U isto vreme LSU su prilagodile svoje javne rashode, koji su ukupno opali za 3,4\% u poređenju sa 2019.

Prihodi od poreza na dohodak čine 40\% ukupnih prihoda LSU, a više od $4 / 5$ ovih prihoda odnosi se na porez na zarade. Drugi po veličini instrumenti finansiranja LSU su periodični porezi na imovinu, a zatim transferi centralnog nivoa vlasti. Ova tri instrumenta finansiranja čine više od $70 \%$ prihoda LSU, dok preostali deo prihoda potiče od poreza na nasledstvo i poklone, poreza na promet imovine, takse za isticanje firme, ostalih lokalnih komunalnih i administrativnih taksi i naknada, kao i drugih neporeskih i poreskih prihoda.

Struktura prihoda LSU (Slika 4), takođe, ukazuje na dominaciju namenskih prihoda i transfera, dok je udeo izvornih prihoda, koji se definišu i naplaćuju od strane LSU, relativno nizak, što u određenoj meri ograničava njihovu autonomiju. Ovo je posledica dizajna sistema javnih finansija, nedostatka podsticaja i relativno niskih napora lokalnih samouprava na prikupljanju prihoda.

Prema podacima na opštinskom nivou, prosečni godišnji prihodi po stanovniku, na uzorku od 27 LSU, iznose 50.600 RSD. Raspodela po lokalnim samoupravama ukazuje na relativno visoku nejednakost $u$ pogledu raspodele prihoda po LSU. Prosečni koeficijent varijacije u uzorku od 27 lokalnih 


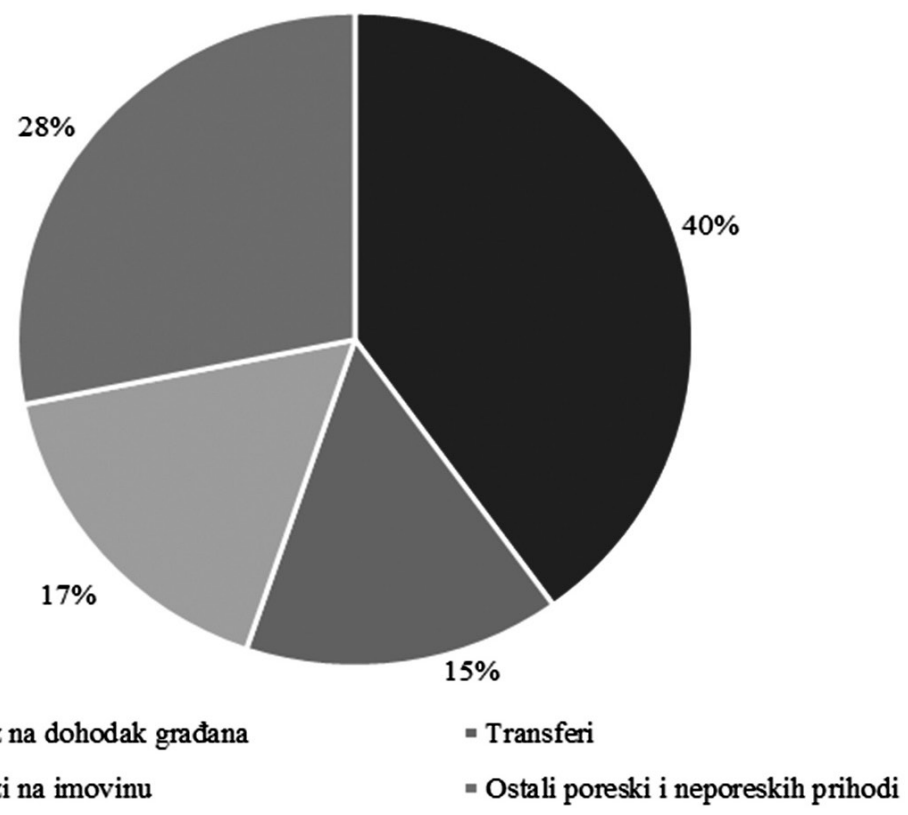

Slika 4 Struktura prihoda LSU u Republici Srbiji u 2019. (\%)

Izvor: Autori

samouprava iznosi 37 (Slika 5), što je posledica dizajna sistema finansiranja lokalnih samouprava i regionalnih nejednakosti u pogledu ekonomskog razvoja. Nejednakost $u$ raspodeli prihoda se, zatim, preslikava $\mathrm{u}$ nejednakost $\mathrm{u}$ raspodeli rashoda, uključujući nejednakost u lokalnim javnim investicijama (Slika 10), sa nepovoljnim uticajem na lokalne i regionalne razlike u pogledu ekonomskog razvoja.

\section{LOKALNA POLITIKA JAVNIH RASHODA}

\section{Institucionalni okvir}

Funkcije i nadležnosti LSU u RS regulisani su Zakonom o lokalnoj samoupravi (2007). Uopšteno govoreći, funkcije lokalnih samouprava u RS slične su ulogama dodeljenim lokalnim samoupravama u mnogim drugim evropskim zemljama i uključuju sledeće:
- izrada planova lokalnog ekonomskog razvoja i olakšavanje poslovanja i uslova za priliv investicija;

- pružanje lokalnih/komunalnih usluga (upravljanje otpadom i vodnosnabedvanjem, grejanje, itd.), javni prevoz i korišćenje građevinskog zemljišta i poslovnih prostora;

- razvoj, održavanje i upravljanje lokalnim putevima i drugom javnom infrastrukturom;

- pružanje pomoći u obezbeđenju usluga $\mathrm{u}$ obrazovanju (predškolsko, osnovno i srednje), pre svega, u pogledu razvoja i održavanja obrazovne infrastrukture (školske zgrade i oprema);

- olakšavanje pružanja usluga $u$ istraživanju i inovacijama, kulturi, zdravstvu (održavanje i razvoj infrastrukture primarne zdravstvene zaštite), socijalnoj zaštiti i sportu;

- podsticanje razvoja turizma, zanatstva, trgovine i ugostiteljstva; 


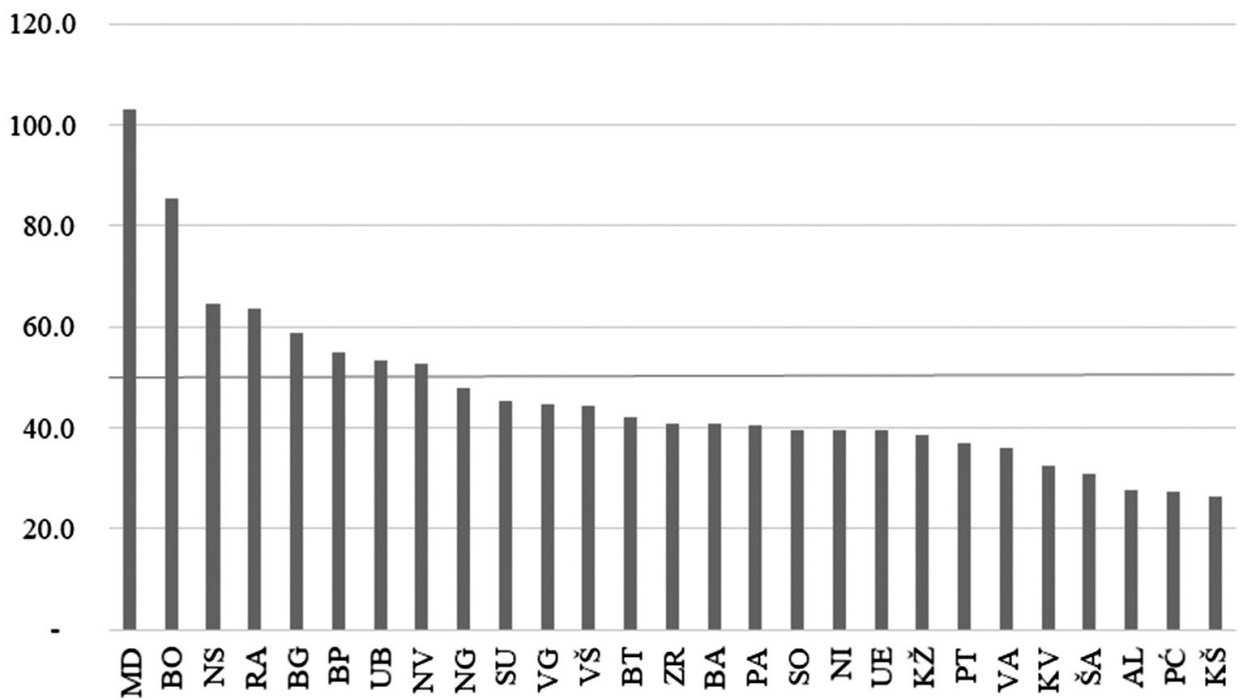

Slika 5 Prihodi LSU po glavi stanovnika u 2019. (hiljada RSD) ${ }^{\mathrm{ii}}$

Izvor: Autori

- pružanje drugih usluga, važnih za lokalni razvoj (građevinska dozvola, zaštita od požara, itd.).

Regulaciju i nadzor nad radom LSU vrši Vlada Republike Srbije - Ministarstvo za državnu upravu i lokalnu samoupravu.

\section{Javni rashodi - struktura i trendovi}

Ukupni rashodi lokalnih samouprava u RS, u 2019, iznosili su 6\% BDP-a, odnosno 14,1\% konsolidovanih rashoda sektora države. Rashodi za robu i usluge predstavljaju najveću pojedinačnu stavku rashoda, sa udelom od 36\% u ukupnoj potrošnji, praćeni ostalim izdacima - uglavnom vezanim za socijalnu zaštitu (22\% ukupne potrošnje) i zaradama (19\% ukupne potrošnje), dok su kapitalni izdaci činili oko jedne šestine ukupne potrošnje LSU (Slika 6).

Zbog rasta prihoda i inflacije, izdaci za LSU u RS, u period 2010-2019), nominalno su porasli za 71,7\%, dok je realni rast (usklađen za inflaciju) iznosio 19,2\% (Slika 7). Ovaj rast je, u velikoj meri, posledica rasta potrošnje na robu i usluge (koje su u tom periodu realno porasle za 90\%). Povećanje neproduktivnih rashoda podstaknuto je naglim prilivom prihoda (zbog reforme raspodele poreza na zarade u 2011), kao i prilično niskim nivoom odgovornosti u pogledu lokalnog upravljanja javnim finansijama i činjenicom da je $\mathrm{u}$ tom periodu na snazi bilo zamrzavanje zapošljavanja $\mathrm{u}$ javnom sektoru, zbog čega su mnoge lokalne samouprave počele da eksterno ugovaraju usluge koje su ranije bile pružane interno.

\section{Lokalna politika javnih investicija}

U periodu 2011-2015, kapitalni izdaci (javne investicije u lokalnu infrastrukturu) bile su u padu, uprkos prilivu dodatnih poreskih prihoda usled reformi implementiranih 2011. i 2014. Lokalne javne investicije počele su da rastu tek 2015, od kada beleže blagi kontinuirani rast. Međutim, u 2019, lokalne javne investicije iznosile su približno 450 miliona evra, što je i dalje niže, za 13\% realno, u odnosu na 2010. U relativnom iznosu, lokalne javne invesitcije u 2019, (Slika 8) iznosile su 1\% BDP-a, čineći tako samo petinu konsolidovanih javnih investicija.

Iako su od 2015, lokalne javne investicije bile u porastu (kako nominalno, tako i realno), one su rasle sporije od investicija centralnog nivoa države, zbog čega je 


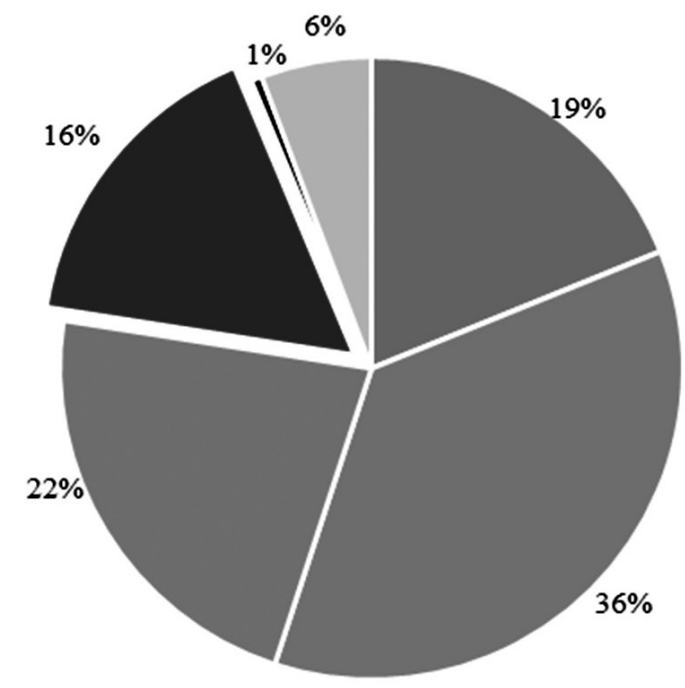

\section{- Zarade - Roba i usluge = Ostali rashodi - Javne investicije - Kamata "Subvencije}

Slika 6 Struktura javnih rashoda LSU u Republici Srbiji u 2019. (\%)

Izvor: Autori

udeo lokalnih javnih investicija u konsolidovanim javnim investicijama kontinuirano opadao, počev od 2011. Tako su 2011, lokalne javne investicije činile 40\% ukupnih konsolidovanih javnih investicija, dok je do 2019, taj udeo prepolovljen (Slika 9).

$\mathrm{U}$ poređenju sa ostalim zemljama, ukupne javne investicije lokalnih samouprava $u$ RS su znatno ispod proseka EU-27 (1,4\% BDP-a) i proseka CIE (1,5\% BDP-a). Nove članice EU iz CIE, u proseku ulažu više iz budžeta lokalnih samouprava, nego razvijene evropske zemlje, kako bi im se približile u pogledu razvijenosti lokalne infrastrukture. Relativno niske lokalne javne investicije $\mathrm{u}$ Republici Srbiji $\mathrm{u}$ poređenju sa ostalim zemljama CIE mogu se donekle objasniti nižom javnom potrošnjom na lokalnom nivou. Podaci, međutim, pokazuju da Republika Srbija ima slabe rezultate i u pogledu udela javnih investicija u ukupnim lokalnim javnim rashodima. Stoga se niske javne investicije lokalnih samouprava u Republici Srbiji mogu objasniti ograničenom decentralizacijom prihoda, slabom politikom javnih finansija na lokalnom nivou i nedostatkom kapaciteta za planiranje i realizaciju infrastrukturnih projekata.

Iako se često tvrdi da je fiskalna decentralizacija na prihodnoj strani potrebna da bi se podstakle javne investicije na lokalnom nivou, podaci (slike 7 i 8) pokazuju da obezbeđenje dodatnih sredstava, verovatno, neće automatski rezultirati porastom javnih investicija, bez promene $\mathrm{u}$ institucionalnom uređenju i kapacitetima i uvođenja sistemskih podsticaja. Bez uvođenja veze između alokacije prihoda i strukture potrošnje LSU (na primer, putem podsticaja za rast $\mathrm{i}$ dobro definisanih pokazatelja učinka), postoji rizik da će se decentralizacija prihoda koristiti za finansiranje stavki rashoda koje daju kratkoročne političke koristi, umesto da se sredstva usmere na razvoj preduslova za dugoročni rast. To ilustruje opadajući udeo javnih investicija lokalnih samouprava u ukupnim rashodima lokalne samouprave - sa 22\% u 2010, na 16\% u 2019 (Slika 9).

Analiza zasnovana na mikro podacima za 2018, za 27 lokalnih samouprava uključenih u uzorak, takođe, 


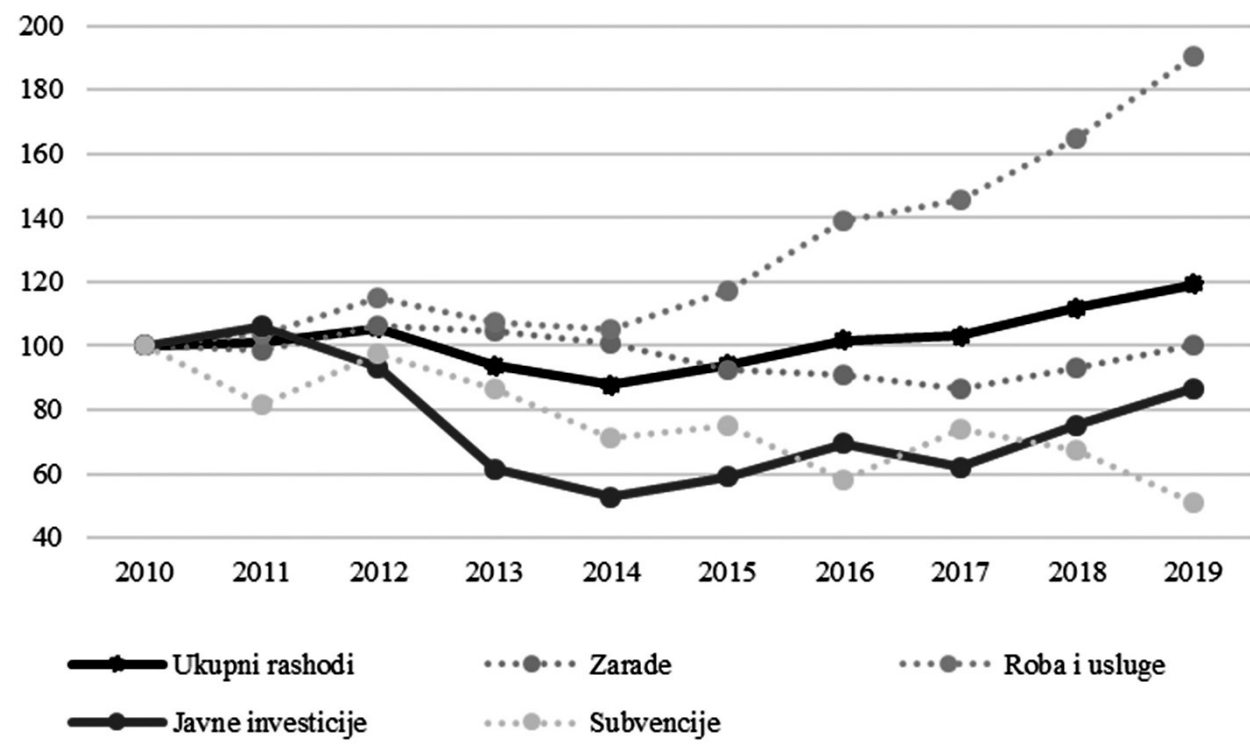

Slika 7 Indeks realne dinamike rashoda LSU (2010=100)

Izvor: Autori

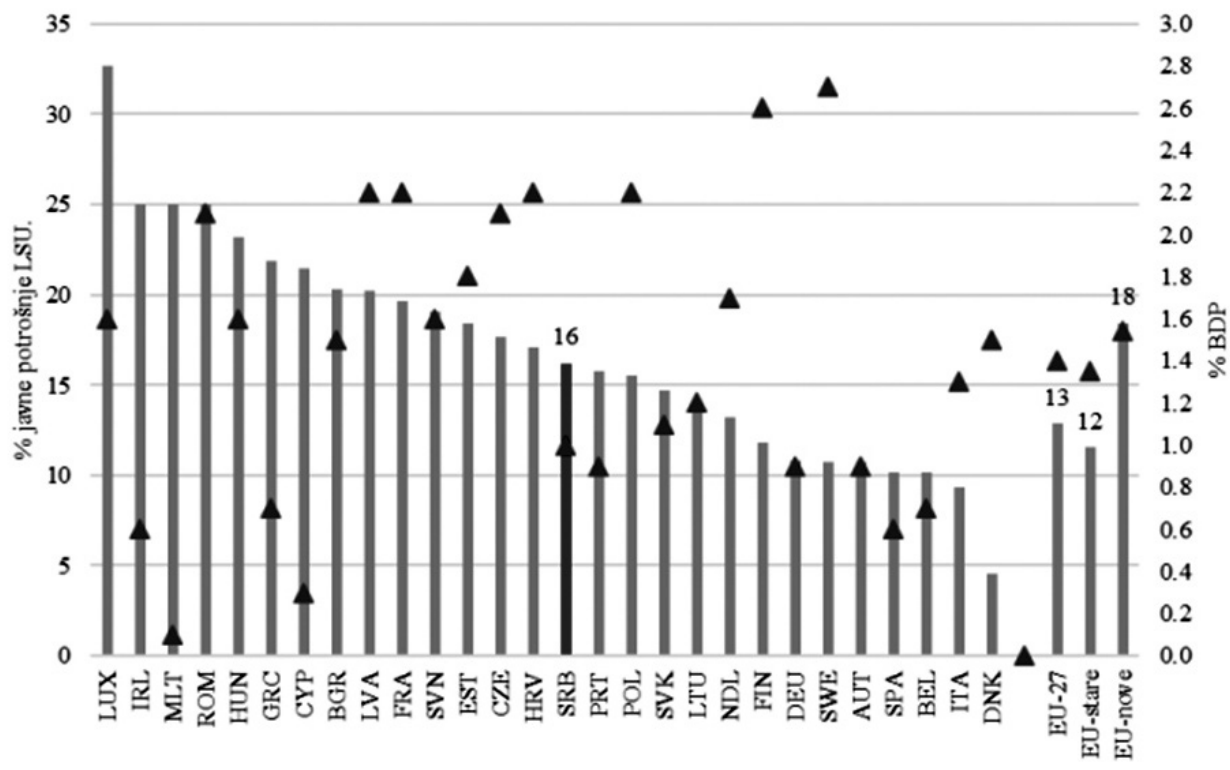

- Javne investicije LSU (\% javne potrosnje LSU)

$\Delta$ Javne investicije LSU (\% BDP)

Slika 8 Lokalne javne investicije u 2019: Republika Srbija versus Evropa 
ukazuje na velike razlike $\mathrm{u}$ relativnom iznosu javnih investicija među lokalnim samoupravama (Slika 10). Prosečno učešće javnih investicija u ukupnim rashodima iznosilo je $13,7 \%$, sa koeficijentom varijacije $44,6 \%$. Velike razlike u lokalnim javnim investicijama mogu biti uzrokovane nedostatkom sistemske veze između instrumenata finansiranja LSU i njihove politike rashoda. Međutim, podaci za lokalne samouprave uključene u uzorak pokazuju da je, u proseku, izvršenje javnih investicija niže za $20 \%$ od iznosa predviđenog godišnjim budžetom, te da je približno prikupljenim prihodima. Ovo ukazuje na to da lokalne samouprave, generalno, sistemski precenjuju budžete kako bi u obzir uzele neizvesnost u pogledu dinamike prihoda i efikasnost u pogledu upravljanja projektima.

Podaci o 27 uzoračkih lokalnih samouprava, takođe, ukazuju na to da su lokalne javne investicije, uglavnom, usmerene na razvoj zajednice $(29 \%)^{\mathrm{iii}} \mathrm{i}$ tradicionalnu rekonstrukciju i održavanje ulica (26,9\%). Ulaganja u obrazovanje, kulturu i sportsku infrastrukturu čine blizu 13\% investicija, dok ulaganja u zelenu infrastrukturu (životna sredina, upravljanje otpadom, vodosnabdevanje i upravljanje otpadnim vodama) čine manje od 6\% ukupnih javnih investicija lokalnih samouprava (Slika 11). S druge strane, veliki deo lokalnih javnih investicija (18,9\%) odlazi na razvoj drugih vrsta infrastrukture, potrebne za pružanje administrativnih i opštih usluga.

Uzimajući u obzir relativno nizak kvalitet putne infrastrukture na lokalnom nivou, nedostatak odgovarajućeg sistema upravljanja otpadom, vodosnabdevanjem ili sistemom upravljanja otpadnim vodama, te nizak kvalitet vazduha, moglo bi se očekivati veće učešće investicija u ove vrste infrastrukture, u ukupnom iznosu kapitalnih izdataka. Prikazani podaci signaliziraju da to nije slučaj, između ostalog, zbog nedostatka sistemskog okvira koji bi podstakao produktivna ulaganja i potencijalno doprineo rekonstrukciji i održavanju kritične infrastrukture. Vlada RS je najavila dugoročni plan javnih investicija „Republika Srbija 2025“, u kojem se ulaganje u lokalnu infrastrukturu navodi kao jedan od prioriteta. S obzirom na to da

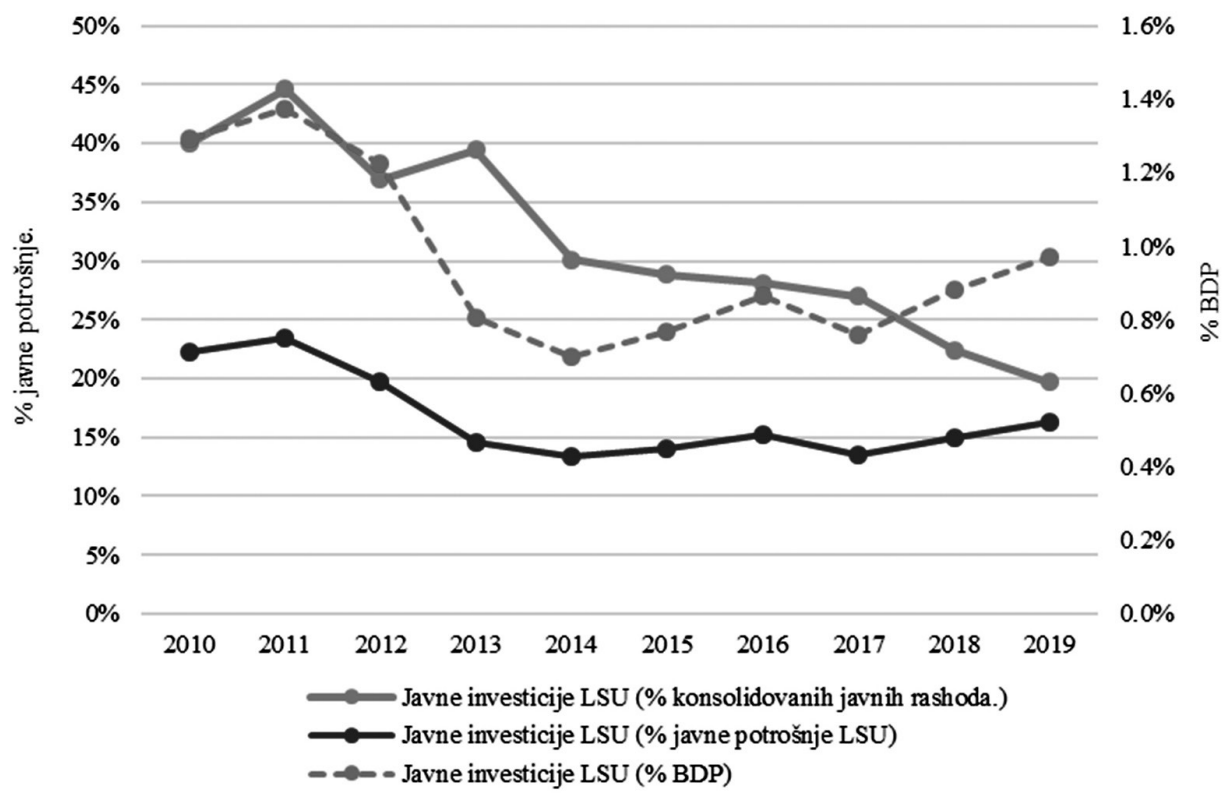

Slika 9 Dinamika lokalnih javnih investicija 


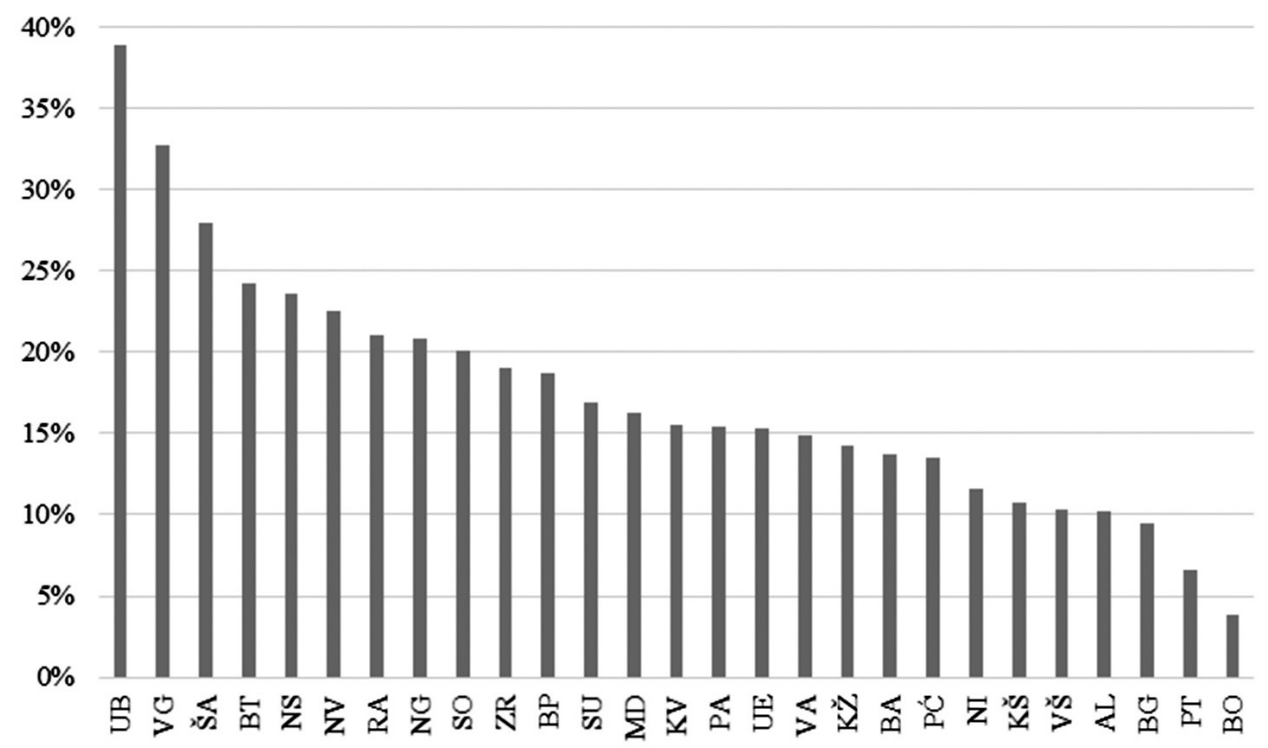

Slika 10 Udeo lokalnih javnih investicija u ukupnim lokalnim javnim rashodima, po LSU (\%)

Izvor: Autori

je uloga LSU da investira i održava komunalnu infrastrukturu, moglo bi se preporučiti da se pomoću investicionog plana uvedu sistemski podsticaji za LSU kako bi povećali napore u pogledu razvoja i rehabilitacije davno zapuštene lokalne infrastrukture, umesto da centralni nivo države bude direktno angažovan na razvoju komunalne infrastrukture. Kreiranje jasnog plana i ciljeva trebalo bi da utiče i na promenu načina razmišljanja, tako da fokus bude na tražnji umesto na ponudi lokalnih dobara, što bi lokalnim samoupravama olakšalo planiranje na srednji i dugi rok.

\section{FISKALNI BILANS LOKALNIH SAMOUPRAVA}

Prema Zakonu o budžetskom sistemu (2009), LSU može da ostvari fiskalni deficit samo u svrhu finansiranja lokalnih javnih investicija. Fiskalni deficit lokalne samouprave, međutim, ne može biti veći od $10 \%$ njenih javnih prihoda u odgovarajućoj godini. U slučaju sprovođenja velikog investicionog projekta, LSU može zatražiti od Ministarstva finansija odobrenje za ostvarenje fiskalnog deficita većeg od ove granice, dok će odluka Ministarstva finansija zavisiti od opravdanosti zahteva i opšteg fiskalnog okvira.

Deficit lokalne samouprave može se finansirati zaduživanjem. Član 33 Zakona o javnom dugu (2005) dozvoljava lokalnim samoupravama da pozajmljuju novac na tržištu, uz pismenu saglasnost Ministarstva finansija. Ukupan dug, prikupljen za finansiranje tekuće likvidnosti, ne može preći 5\% ukupnih prihoda u poslednjih godinu dana. S druge strane, dugoročno zaduživanje je dozvoljeno samo u svrhu finansiranja javnih investicija ili otplate dugova, uz sledeća ograničenja:

- dugoročni dug ne može biti veći od $50 \%$ budžeta LSU u prethodnoj godini;

- izdaci za plaćanje kamata i otplatu duga ne smeju preći 15\% tekućih prihoda LSU u odgovarajućoj godini.

LSU ne smeju da izdaju garancije. Fiskalna pravila lokalne samouprave, utvrđena Zakonom o 


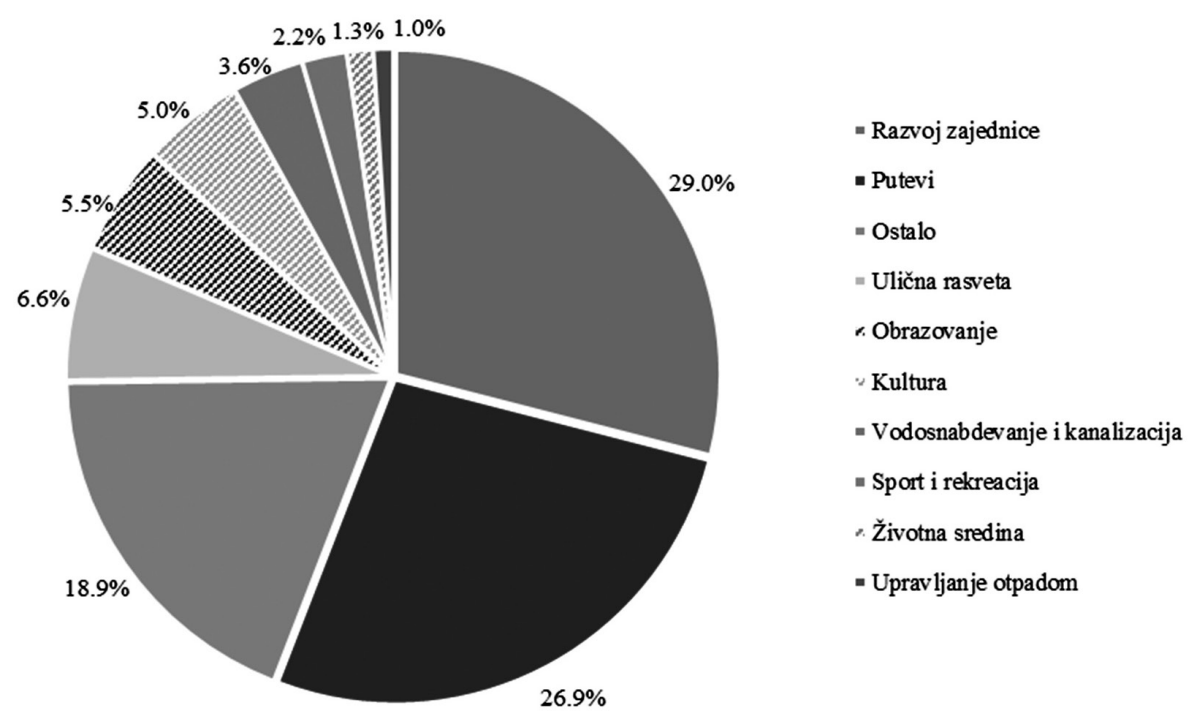

Slika 11 Struktura lokalnih javnih investicija (\%)

Izvor: Autori

budžetskom sistemu (2009), u skladu su sa pravilima o zaduživanju, predviđenim Zakonom o javnom dugu (2005).

U poslednjoj deceniji (2020-2019), LSU u RS uglavnom su ostvarivale fiskalni suficit, dok je deficit na nivou svih LSU zabeležen samo u 2012, 2013 i 2019. Prosečni fiskalni bilans LSU u RS, u periodu 20102019, iznosio je blizu 5,5 milijardi dinara (suficit), što je ekvivalentno 2,8\% njihovih ukupnih prihoda (Slika 12). Ovo je znatno ispod gornje granice deficita (10\% javnih prihoda), kako je utvrđeno Zakonom o budžetskom sistemu (2009). U istom vremenskom periodu, ukupni rashodi na otplatu kamata i izdaci koji se odnose na otplatu duga u LSU u RS iznosili su 12 milijardi dinara (blizu 100 miliona evra) godišnje, odnosno, ekvivalentno 5,5-6\% njihovih prihoda, što je, takođe, daleko ispod zakonske granice (15\% prihoda).

\section{ZAKLJUČAK}

Empirijske studije pokazuju da su u poslednje dve decenije LSU u Republici Srbiji ostvarile konvergenciju unutar dva klastera, dok beogradski okrug ne pokazuje znake konvergencije ni sa jednim ni sa drugim klasterom (Barrios et al, 2020). Uprkos konvergenciji klubova, i dalje postoje značajne lokalne i regionalne razlike, koje podstiču migracije produktivnog stanovništva ka razvijenijim regionima, podrivajući na taj način šanse za konvergenciju nerazvijenih područja. Rezultati empirijskih studija pokazuju da čak i relativno male promene u ekonomskim nejednakostima mogu imati velike efekte na obim migracija (Denett, 2014). U ovom radu analiziran je stepen fiskalne decentralizacije $u$ RS i karakteristike lokalnih politika javnih finansija, sa fokusom na politiku javnih investicija na lokalnom nivou, jer je, strateški posmatrano, zeleni rast, kao i rast orijentisan ka razvoju lokalne infrastrukture jedan od ključnih preduslova za ekonomski razvoj.

Rezultati, prezentovani u ovom radu, dovode do nekoliko bitnih naučnih i praktičnih zaključaka. Utvrđeno je da su LSU u RS prilično velike, posebno $\mathrm{u}$ pogledu prosečnog broja stanovnika, u poređenju sa evropskom praksom. Istovremeno, stepen fiskalne decentralizacije u RS je ispod evropskog proseka. Javni prihodi i rashodi lokalne samouprave ( $\mathrm{u}$ 


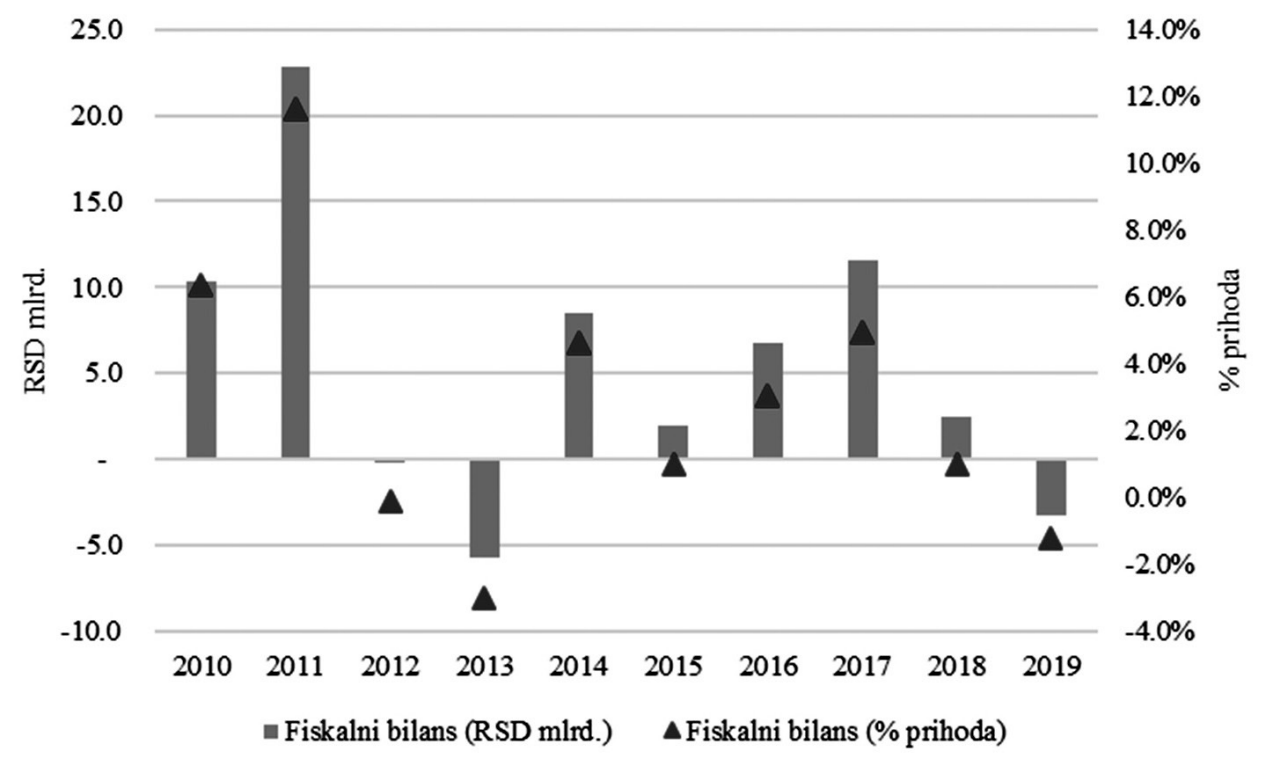

Slika 12 Dinamika fiskalnog bilansa lokalnih samouprava, 2010-2019.

Izvor: Autori

odnosu na BDP) u RS su niži od proseka EU i CIE. Tri najveća instrumenta za prikupljanje prihoda LSU su porez na dohodak građana, porezi na imovinu i transferi centralnog nivoa države, koji čine gotovo $3 / 4$ ukupnih lokalnih javnih prihoda. Više od polovine prihoda LSU se dodeljuje, ili prenosi, od strane centralnog nivoa države, što ukazuje na nizak stepen fiskalne autonomije. Dobijeni pokazatelji sugerišu da su lokalne javne investicije u RS niske, dok je varijacija njihove relativne visine po LSU velika. Tako, na strani lokalnih javnih rashoda, glavne stavke predstavljaju nabavka dobara i usluga i zarade, koje čine 55\% ukupnih rashoda, dok je udeo javnih investicija u ukupnim izdacima LSU tek 16\% (što čini samo petinu konsolidovanih javnih investicija). Relativna veličina javnih investicija LSU u RS (1\% BDP-a) je znatno ispod proseka CIE (1,4\% BDP-a). Decentralizacija dodatnih javnih prihoda, sprovedena početkom prethodne decenije, nije dovela do rasta lokalnih javnih investicija, već su one u znatnom delu tog perioda čak i opadale. Javne investicije LSU u RS su, uglavnom, orijentisane na razvoj zajednice i tradicionalnu rekonstrukciju i održavanje ulica, dok su ulaganja u obrazovanje, kulturu i sportsku infrastrukturu kao i u infrastrukturu životne sredine prilično niska. Uprkos porastu ukupnih prihoda (na primer, decentralizacija prihoda od poreza na zarade), tokom poslednje decenije, javne investicije LSU zabeležile su realan pad. Činjenica da je značajan broj LSU imao niska javna ulaganja, čak i u periodima kada su imale budžetski suficit, ukazuje da se, pored fiskalnih ograničenja, neke od njih suočavaju i sa ograničenjima u pogledu svojih kapaciteta za planiranje i sprovođenje investicionih projekata. Nizak nivo lokalnih javnih investicija i činjenica da se one nisu povećale ni kada su prihodi porasli, signaliziraju da lokalnim samoupravama nedostaju kapaciteti za srednjoročno i dugoročno planiranje i da institucionalnom dizajnu sistema finansiranja lokalnih samouprava nedostaju sistematski podsticaji za lokalne investicije usmerene na rast i razvoj. To je zbog toga što iznos prihoda koje lokalne samouprave ostvaruju, kao i transferi koje dobijaju od centralne države, ne zavise od kvaliteta i efikasnosti njihove fiskalne politike. Skorašnje promene planskih propisa u RS, koje zahtevaju pripremu razvojnih planova (za period od sedam godina) i srednjoročnih planova (za period od tri godine), mogle bi predstavljati 
mehanizam za unapređenje planskih kapaciteta ukoliko se budu pravilno pripremili i kontrolisali. Pouke iz uporedne (međunarodne) prakse ukazuju da uvođenje sistemskih podsticaja može biti efikasno za trajnije i održivije povećanje (zelenih) javnih investicija. Rečje o podsticajima koji nagrađuju lokalne samouprave koje veći deo svoje javne potrošnje usmeravaju u produktivne svrhe. Uz to, sistemski pristup reformi javne uprave, koji bi rezultirao poboljšanjem administrativnih, tehničkih i planskih kapaciteta, takođe, može doprineti unapređenju ukupne efikasnosti lokalne politike javnih investicija.

Shodno prethodno navedenom, naučna relevantnost dobijenih rezultata odnosi se na razmatranje veze između fiskalne decentralizacije $\mathrm{i}$ javnih investicija, a posebno na povezanost dinamike javnih prihoda $\mathrm{i}$ visine lokalnih javnih investicija, u uslovima odsustva sistemskih podsticaja za investicije. Osim toga, dobijeni rezultati pružaju relevantne uvide za kreatore javnih politika, budući da se $\mathrm{u}$ radu, pored analize stanja, identifikuju i uzroci niskih lokalnih javnih investicija, kao i ključne institucionalne barijere za njihovo povećanje. Analiza u ovom radu zasnovana je na metodama deskriptivne statističke analize. Za pružanje dodatnih uvida u pogledu veze između nivoa fiskalne decentralizacije $i$ visine lokalnih javnih investicija, bilo bi neophodno, primenom relevantnih metoda ekonometrijske analize, kontrolisati uticaj drugih faktora. Osim toga, pored odnosa fiskalne decentralizacije i lokalnih javnih investcija, relevantnim se smatra i pitanje uticaja visine i strukture lokalnih javnih investicija na lokalni ekonomski razvoj, što može predstavljati relevantno pitanje za buduća istraživanja.

\section{ENDNOTE}

S obzirom na to da su ekonomska i fiskalna kretanja u 2020, bila pod uticajem vanrednih događaja uzrokovanih pandemijom COVID-19, razmatranje strukturnih karakteristika politike lokalnih javnih finansija za osnovu podataka za 2020, može dovesti do pogrešnih zaključaka, zbog čega je uzorak ograničen na period do 2019. Podaci za RS, uključeni u ovu analizu, odnose se na teritoriju Republike Srbije bez Kosova i Metohije*, koje je prema rezoluciji 1244 Saveta bezbednosti Ujedinjenih nacija formalno pod upravom UN od 1999.

ii Podaci se odnose na 2019. Podaci o rashodima po glavi stanovnika, po LSU, prikazani na Slici 10, odnose se na 2018, što je i poslednja godina za koju su podaci o rashodima po lokalnim samoupravama raspoloživi.

iii Prema zvaničnoj COFOG klasifikaciji, razvoj zajednice obuhvata: poslove i usluge administriranja razvoja zajednice - administriranje zoniranja, korišćenja zemljišta i izgradnje, regulisanje i planiranje novih zajednica ili rehabilitacije zajednice, planiranje unapređenja i razvoja objekata, kao što su objekti za stanovanje, industriju, javni komunalni objekti, zdravstvo, obrazovanje, kulturu, rekreaciju itd, pripremu shema finansiranja razvoja; pripremu i širenje opštih informacija, tehničke dokumentacije i statistika u vezi sa poslovima i uslugama povezanim sa razvojem zajednice.

\section{REFERENCE}

Akai, N., \& Sakata, M. (2002). Fiscal decentralization contributes to economic growth: Evidence from state-level cross-section data for the United States. Journal of urban economics, 52(1), 93108. doi.org/10.1016/S0094-1190(02)00018-9

Aristovnik, A. (2012). Fiscal Descentralization in Eastern Europe: Trends and selected issues. Transylvanian Review of Administrative Sciences, 8(37), 5-22. doi:10.2139/ssrn.2187475

Arsić, M., Ranđelović, S., Bućić, A.i Vasiljević, D. (2012). Reforme poreza na imovinu u Srbiji: Rezultati i perspektive. Beograd, RS: Univerzitet u Beogradu - Ekonomski fakultet, Fondacija za razvoj ekonomske nauke.

Arsić, M., Ranđelović, S. i Nojković, A. (2019). Uzroci i posledice niskih investicija u Srbiji. U M. Zec i O. Radonjić (Ur.). Ekonomska politika Srbije u 2019. godini (str. 63-84). Beograd, RS: Univerzitet u Beogradu - Ekonomski fakultet.

Barrios, M. C., Jandrić, M., Molnar, D., \& Tanasković, S. (2021). Convergence clubs in different regions of Serbia. Applied Economics Letters, 28(7), 594-598. doi.org/10.1080/13504851.2 020.1765960

Baskaran, T., \& Feld, L. P. (2013). Fiscal decentralization and economic growth in OECD countries: Is there a relationship? Public finance review, 41(4), 421-445. doi.org/10.1177/1091142112463726 
Bird, R. M. (2000). Intergovernmental fiscal relations: Universal principals, local applications. Working Paper 00-2, Georgia State University, Andrew Young School of Policy Studies, Atlanta.

Bodman, P. (2011). Fiscal decentralization and economic growth in the OECD. Applied Economics, 43(23), 3021-3035. doi.org/10.1080/00036840903427208

Dennett, A. (2014). Quantifying the effects of economic and labour market inequalities on inter-regional migration in Europe-a policy perspective. Applied Spatial Analysis and Policy, 7(1), 97-117. doi:10.1007/s12061-013-9097-4

Dziobek, C. H., Mangas, C. A. G., \& Kufa, P. (2011). Measuring fiscal decentralization: Exploring the IMF's databases. IMF Working Papers, 11(126).

Martinez-Vazquez, J., \& McNab, R. M. (2003). Fiscal decentralization and economic growth. World development, 31(9), 1597-1616. doi.org/10.1016/S0305750X(03)00109-8

Molnar, D. (2014). Fiskalna decentralizacija i privredni rast: Evropska unija i Srbija. Reforme i razvoj, 73.

Oates, W. E. (1972). Fiscal Federalism. New York, NY: Harcourt Brace Jovanovich

Petrović, P., Arsić, M., \& Nojković, A. (2021). Increasing public investment can be an effective policy in bad times: Evidence from emerging EU economies. Economic Modelling, 94, 580597. doi:10.1016/j.econmod.2020.02.004

Ministarstvo finansija. (2020). Public Finance Bulletin No. 12/2020. Ministry of Finance of the Republic of Serbia, Belgrade. Retrieved Marc 14. 2021. from: https://www.mfin. gov.rs//upload/media/K1WfqN_6042278628737.pdf

Ranđelović, S. (2020). Pro-growth public investment policy in Serbia: Sufficiency and efficiency. Ekonomika preduzeća, 68(12), 137-146. doi:10.5937/EKOPRE2002137R
Ranđelović, S. (2021). Determinants of volatility of economic activity in Europe during the Covid-19 pandemic: Stylized facts. Ekonomika preduzeća, 69(3-4), 231-242. doi:10.5937/ EKOPRE2103231R

Rosen, H. S., \& Gayer, T. (2014). Public Finance, $10^{\text {th }}$ edition. New York, NY: McGraw-Hill Irwin.

Stansel, D. (2005). Local decentralization and local economic growth: A cross-sectional examination of US metropolitan areas. Journal of Urban Economics, 57(1), 55-72. doi:10.1016/j. jue.2004.08.002

Stigler, G. (1957). The Tenable Range of Functions of Local Government. In Federal Expenditure Policy for Economic Growth and Stability (pp. 213-219). US Congress Joint Economic Committee, Government Printing Office, Washington, DC.

Tiebout, C. M. (1956). A Pure Theory of Public Expenditures. Journal of political economy, 64(5), 416-424.

Zakon o budžetskom sistemu. (2009). Sl. glasnik RS, br. 54/2009, 73/2010, 101/2010, 101/2011, 93/2012, 62/2013, 63/2013 - ispr., 108/2013, 142/2014, 68/2015 - dr. zakon, 103/2015, 99/2016, 113/2017, 95/2018, 31/2019, 72/2019 i 149/2020).

Zakon o finansiranju lokalne samouprave. (2006). Sl. glasnik RS, br. 62/2006, 47/2011, 93/2012, 99/2013 - usklađeni din. izn., 125/2014 - usklađeni din. izn., 95/2015 - usklađeni din. izn., 83/2016, 91/2016 - usklađeni din. izn., 104/2016 - dr. zakon, 96/2017 - usklađeni din. izn., 89/2018 - usklađeni din. izn., 95/2018 - dr. zakon, 86/2019 - usklađeni din. izn. i 126/2020 - usklađeni din. izn.).

Zakon o javnom dugu. (2005). Sl. glasnik RS, br. 61/2005, 107/2009, 78/2011, 68/2015, 95/2018, 91/2019 i 149/2020).

Zakon o lokalnoj samoupravi. (2007). Sl. glasnik RS, br. 129/2007, 83/2014 - dr. zakon, 101/2016 - dr. zakon i 47/2018).

Zakon o teritorijalnoj organizaciji Republike Srbije. (2007). Sl. glasnik RS, br. 129/2007, 18/2016, 47/2018 i 9/2020 - dr. Zakon). 
Primljeno 9. juna 2021, nakon revizije, prihvaćeno za publikovanje 25. novembra 2021. Elektronska verzija objavljena 6. decembra 2021.

Saša Ranđelović je vanredni profesor na Ekonomskom fakultetu Univerziteta u Beogradu. Doktorat iz ekonomije stekao je na Ekonomskom fakultetu Univerzitetu u Beogradu. Njegovo polje istraživanja uključuje javne finansije i fiskalnu politiku.

Svetlana Vukanović je viši specijalista za saobraćaj u Svetskoj banci. Vodila je niz infrastrukturnih projekata širom Zapadnog Balkana. Doktorirala je na Minhenskom tehnološkom univerzitetu. 


\title{
FISCAL DECENTRALIZATION AND LOCAL PUBLIC INVESTMENT POLICY IN THE REPUBLIC OF SERBIA
}

\author{
Sasa Randjelovic' and Svetlana Vukanovic ${ }^{2}$ \\ 'University of Belgrade, Faculty of Economics, Belgrade, The Republic of Serbia \\ ${ }^{2}$ The World Bank, Belgrade, The Republic of Serbia
}

This paper analyses the level of fiscal decentralization and structural characteristics of local public finances in Republic of Serbia with focus on local public investments. Share of central government expenditures in consolidated government spending of $83 \%$, indicates relatively high degree of fiscal centralization. In spite of significant rise in local public revenues in the last decade public investments remained low - amounting to 1\% of GDP, which is significantly below EU and Central and Eastern Europe average (1.4 and 1.5\% GDP, respectively). Our results indicate large variation in relative size of public investments across LSGs. Most local public investments are focused on roads maintenance administrative infrastructure, while investments in environment and education are low. To tackle local disparities in terms of quality of local infrastructure and to foster economic convergence, development of planning and implementation capacities and introduction of systemic incentives for local public investments should be considered.

Keywords: fiscal decentralization, local self-government, public finance, local-level public investments

JEL Classification: H70, H71, H72, H74 